\title{
Environmental and Economic Sustainability of Swine Wastewater Treatments Using Ammonia Stripping and Anaerobic Digestion: A Short Review
}

\author{
Adele Folino ${ }^{1}$, Demetrio Antonio Zema ${ }^{1, *(1)}$ and Paolo S. Calabrò ${ }^{2}$ (i) \\ 1 Department Agraria, Mediterranea University of Reggio Calabria, Località Feo di Vito, \\ I-89122 Reggio Calabria, Italy; adelefolino@alice.it \\ 2 Department Diceam, Mediterranea University of Reggio Calabria, Via Graziella, Località Feo di Vito, \\ I-89124 Reggio Calabria, Italy; paolo.calabro@unirc.it \\ * Correspondence: dzema@unirc.it
}

Received: 30 April 2020; Accepted: 16 June 2020; Published: 18 June 2020

\begin{abstract}
One of the most promising systems to treat swine wastewater is air stripping. This system simultaneously recovers nitrogen salts, to be used as fertiliser, and reduces the organic pollutant load in the effluents of swine breeding farms. Several reviews have discussed the air stripping as a treatment for many types of industrial wastewater or nitrogen-rich digestate (the liquid effluent derived from the anaerobic digestion plants) for the stripping/recovery of nutrients. However, reviews about the use of air stripping as treatment for raw or anaerobically digested swine wastewater are not available in literature. To fill this gap, this study: (i) Summarises the experiences of air stripping for recovery of ammonium salts from both raw and digested swine wastewater; and (ii) compares air stripping efficiency under different operational conditions. Moreover, combined systems including air stripping (such as struvite crystallisation, chemical precipitation, microwave radiation) have been compared. These comparisons have shown that air stripping of raw and digested swine wastewater fits well the concept of bio-refinery, because this system allows the sustainable management of the piggery effluent by extracting value-added compounds, by-products, and/or energy from wastewater. On the other hand, air stripping of raw and digested swine wastewater has not been extensively studied and more investigations should be carried out.
\end{abstract}

Keywords: air stripping; ammonia removal efficiency; ammonium sulphate; digestate; nitrogen recovery; process conditions; struvite

\section{Introduction}

The management of swine wastewater (hereinafter indicated as "SW") is an important problem for swine breeding farms, as the large production and polluting content lead to several environmental and economic constraints and a generally low sustainability. Due to the high contents of organic and nitrogen compounds, unproper disposal of SW causes pollution of surface and ground waters, unpleasant odour emission in atmosphere, and consumption of oxygen in soil and water bodies.

Intensive depuration plants are the most common systems for SW treatment [1]. Other chemical (such as coagulation/flocculation [2-4]), physical [5], or biological (multi-stage or aerobic treatment [1,6]) systems [6-8] have been proposed to ensure an environmentally and economically sound management of SW (Table 1). However, these treatments generally show low efficiency, high costs [9], and process instability, mainly due to the high concentration of ammonia nitrogen that inhibits the microorganisms' activity. When chemicals are added to the processes (e.g., coagulation/flocculation), the resulting sludge/concentrate cannot be directly spread in agricultural fields, as it may contain undesired 
by-products of the chemical process or toxic compounds (e.g., heavy metals) [2,4]. Moreover, secondary pollution may occur [10] and other subsequent treatments may be necessary for the produced sludge/concentrate.

Table 1. Advantages and drawbacks of the main systems for the treatment of swine wastewater.

\begin{tabular}{|c|c|c|c|}
\hline Treatment & Type & Advantages & Limitations \\
\hline Chemical & $\begin{array}{l}\text { Coagulation - Flocculation - } \\
\text { Disinfection (possible) }\end{array}$ & 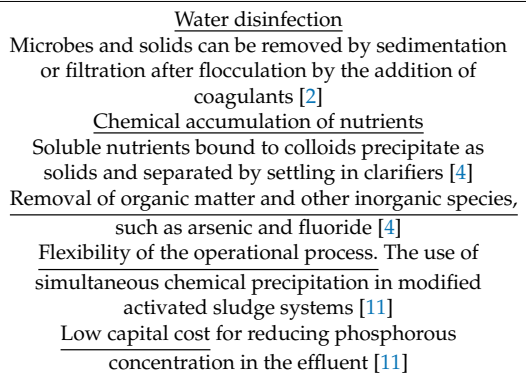 & $\begin{array}{l}\begin{array}{c}\text { Possible undesired by-products, such as } \\
\text { trihalomethanes and chlorites in case of } \\
\text { chlorination [2] }\end{array} \\
\text { Variability of process conditions depending on the } \\
\begin{array}{c}\text { level of disinfection required [2] } \\
\text { Operating costs [11] }\end{array} \\
\frac{\text { Sludge production and possible presence }}{\text { of heavy metals [11] }} \\
\text { fossible inhibitory effects in the } \\
\text { following biological treatment [12] } \\
\text { Low nutrients availability and agronomic utilisation, } \\
\text { particularly with aluminium and iron coagulation [13] }\end{array}$ \\
\hline \multirow[t]{2}{*}{ Physical } & Sedimentation & $\begin{array}{l}\text { Fertiliser production by bio-solid recovery [2] } \\
\text { Pathogens reduction, such as Salmonella typhimurium, } \\
\text { E. coli, Streptococcus faecalis [2] } \\
\frac{\text { Reduction of the organic load for the following }}{\text { treatments }[2]}\end{array}$ & \multirow{2}{*}{$\begin{array}{l}\text { Energy costs of filtration membranes [4] } \\
\text { Not suitable direct use of the concentrate due to the } \\
\text { accumulation of undesired contaminants [4] } \\
\text { Pre-treatment needed to prevent membrane fouling [4] } \\
\text { High cost for membrane replacement due to fouling }\end{array}$} \\
\hline & Membrane filtration & $\begin{array}{l}\text { Selective separation of the constituents from } \\
\text { waste streams based on the membrane used [4] }\end{array}$ & \\
\hline $\begin{array}{l}\text { Biological } \\
\text { system }\end{array}$ & Activated sludge process & $\frac{\text { Odour control, nitrogen management, }}{\text { and biodegradation of organic waste [2] }}$ & $\begin{array}{l}\text { Possible inhibition due to the presence of } \\
\text { toxic compounds (such as resistant pathogens, heavy } \\
\text { metals, other organic compounds) } \\
\text { Process sensitivity to environmental conditions (pH, } \\
\text { temperature, organic load) }\end{array}$ \\
\hline
\end{tabular}

Often, most of these treatments are not sustainable for the smallest swine-breeding farms working in rural contexts. For these reasons, much attention has been recently paid to extensive systems for SW depuration, such as the aerobic and/or anaerobic lagooning plants (e.g., [14-16]). These extensive systems allow a proper equalisation of the physico-chemical characteristics of wastewater and a reduction of its pollutant load, as for other agro-industrial effluents [17-19]. However, the physico-chemical and biological processes of lagooning plants require a long time (weeks or even months), because the environmental conditions cannot be properly set up. Another viable system for SW treatment is the anaerobic digestion, which allows an easier control of the main operational parameters of the depuration process. The anaerobic digestion systems are used for depurating several agro-industrial waste and wastewater, such as the olive mill wastewater or citrus peel waste and wastewater [20-22]. However, the methane production in the anaerobic digestion plants treating SW is often reduced or even inhibited by the high ammonia content (often over $4.0 \mathrm{~g} \mathrm{~L}^{-1}$ ) that hampers the activity of the methanogenic bacteria $[23,24]$. As a consequence, the methane yield of raw SW is about $50 \mathrm{~mL} \mathrm{gCO}^{-1}[23,25]$ or $100-200 \mathrm{~mL} \mathrm{gVs}^{-1}[24,26]$. As the $\mathrm{SW}$ has a high organic and nutrient loads, the treatment efficiency is not always high and the limits for discharging the treated effluents into water bodies are very strict in some countries (such as Italy), the depurated SW very often is spread on soil for agronomic purposes or sent to further treatments, such as lagooning and constructed wetlands.

On the other hand, the high presence of ammonium and phosphorus compounds has suggested the recovery of natural fertilisers from SW using physico-chemical treatments. Examples of these recovered compounds are struvite (either in magnesium, $\mathrm{MgNH}_{4} \mathrm{PO}_{4}$, or potassium, $\mathrm{KNH}_{4} \mathrm{PO}_{4}$, form) $[27,28]$ and ammonium sulphate [25]. Nitrogen and phosphorus are essential nutrients for plant growth and crop cultivation, but their production is often expensive. The removal of these compounds from SW not only allows their recovery, but also makes the following treatments easier, leading to a more efficient depuration in lagooning plants and to an increase of the methane yield in anaerobic digestion systems. 
The most common system for ammonia recovery is air stripping. This system consists of blowing air in wastewater, which is also chemically pre-treated by adding alkali-such as $\mathrm{NaOH}, \mathrm{Ca}(\mathrm{OH})_{2}$, or $\mathrm{CaO}$ - in order to optimise its $\mathrm{pH}$ before aeration. The stripped ammonia is recovered by an adsorbing unit as ammonium sulphate, an inorganic salt that can be directly used as a fertiliser. Moreover, when air stripping is used as a pre-treatment for the SW, the risk of ammonia inhibition is lower; for the direct use of the digestate in agriculture, a simple solid-liquid separation without other chemical treatments is only required.

An alternative plant scheme is the air stripping of digested wastewater. The effluents of anaerobic digestion, if influent SW is not pre-treated, usually show a high nitrogen content even after the anaerobic digestion. Moreover, the high water content and the possible presence of contaminants (such as heavy metals and organic matter) often makes the digestate not suitable for direct spreading on land [4]. In these cases, air stripping is also applied to reduce the ammonia nitrogen content, in order to allow the valorisation of the digestate as soil conditioner, thus increasing the sustainability of the whole management processes.

The literature reports several reviews on AS of wastewater of different sources, such as municipal or industrial wastewater [4,27,29-32] as well as of urine [33] and manure [34], and about recovery of nutrients from digestate $[35,36]$. However, no reviews have been published on ammonia removal from raw or digested SW by air stripping. In order to fill this gap, this review analyses the AS techniques and their performances on both raw and digested SW. Based on the most important studies found in literature, the state of the art is outlined and the future research directions are suggested, to further improve the technical, economic, and environmental sustainability of AS of raw SW and digested SW.

\section{Air Stripping}

Air stripping is one of the most common systems for removing volatile pollutants, especially ammonia, from aqueous solution [31], because it is a relatively simple and cost-effective process [32,37]. However, the industrial application of air stripping is still in its preliminary phase [31]. Thus, more research is needed to consolidate its practical use [4]. The removal efficiency of air stripping mainly depends on four parameters: (i) $\mathrm{pH}$; (ii) temperature; (iii) air flow per unit volume of wastewater (hereinafter "air flow rate", AFR); and (iv) characteristics of the raw wastewater [25,38,39]. The following sub-sections explain the effects of the operational parameters $(\mathrm{pH}$, temperature, and AFR) on the removal efficiency of ammonia nitrogen and the main drawbacks in air stripping application; then, the processes of nutrient recovery and the alternative schemes of air stripping in literature are discussed.

\subsection{Effects of the Operational Parameters on the Removal Efficiency of Ammonia Nitrogen and Main Drawbacks of Air Stripping Application}

Basically, air stripping consists of a mass transfer based on a desorption process, which transfers a gas from the liquid to a gas phase. For SW (the liquid phase), ammonia can be found as ammonium ions (the ionic form, $\mathrm{NH}_{4}^{+}$) and ammonia gas (the molecular form, $\mathrm{NH}_{3}$ ) [32], which are in equilibrium according to the following reaction (Equation (1)) [32]:

$$
\mathrm{NH}_{3}+\mathrm{H}_{2} \mathrm{O} \Leftrightarrow \mathrm{NH}_{4}^{+}+\mathrm{OH}^{-}
$$

The distribution between molecular ammonia and ammonium ions, described by Equation (2) [39], depends on $\mathrm{pH}$ and temperature, as explained by Equation (3) [38]:

$$
\begin{gathered}
{\left[\mathrm{NH}_{3}\right]=\frac{\left[\mathrm{NH}_{3}+\mathrm{NH}_{4}^{+}\right]}{1+\left[\mathrm{H}^{+}\right] / \mathrm{K}_{a}}} \\
p K_{a}=4 \cdot 10^{-8} \mathrm{~T}^{3}+9 \cdot 10^{-5} \mathrm{~T}^{2}+0.0356 \mathrm{~T}+10.072
\end{gathered}
$$


where $\left[\mathrm{NH}_{3}\right]$ is the molecular ammonia concentration $\left[\mathrm{mol} \mathrm{L}^{-1}\right],\left[\mathrm{NH}_{3}+\mathrm{NH}_{4}{ }^{+}\right]$is the total ammonia nitrogen (TAN) concentration $\left[\mathrm{mol} \mathrm{L}^{-1}\right],\left[\mathrm{H}^{+}\right]$is the hydrogen ion concentration $\left[\mathrm{mol} \mathrm{L}^{-1}\right], \mathrm{Ka}$ is the acid ionization constant, and $\mathrm{T}$ is the temperature [ $\left.{ }^{\circ} \mathrm{C}\right]$ [40]; $\mathrm{pK} \mathrm{a}$ is equal to $-\log _{10}\left(\mathrm{~K}_{\mathrm{a}}\right)$ [dimensionless]. If the $\mathrm{pH}$ is acidic, neutral, or slightly alkaline $(<8.0-8.5)$, the equilibrium reaction shown in the Equation (1) is displaced to the right, while, if $\mathrm{pH}$ increases (>8.5), the formation of molecular ammonia is enhanced (Table 2) [31,40-42].

Table 2. Effects of variations of parameters on air stripping system.

\begin{tabular}{ccc}
\hline Parameter & Variation & Effect on Air Stripping \\
\hline $\mathrm{pH}$ & $\uparrow$ & $\uparrow$ \\
Temperature & $\uparrow$ & $\uparrow$ \\
Air flow rate & $\perp$ & $\perp$ \\
\hline
\end{tabular}

A scheme of the air stripping process is shown in Figure 1. As the aim of the treatment is the removal of ammonia nitrogen compounds (both the ionic and molecular forms) from the SW, the $\mathrm{pH}$ increase over a certain threshold allows the conversion of almost all the content of $\mathrm{NH}_{4}{ }^{+}$into the gaseous form, $\mathrm{NH}_{3}$. Hence, the first step of the process generally consists of the addition of an alkali solution to the raw $\mathrm{SW}$, in order to increase its $\mathrm{pH}$. Then, in the second unit, the mass transfer of $\mathrm{NH}_{3}$ from SW is enhanced by the aeration that alters the air-liquid boundary [31]. Temperature plays an important effect on the removal of molecular ammonia from wastewater, since the solubility of ammonia in water, according to Henry's law, is governed by the temperature as well as by solute and solvent amounts $[27,32,40,43]$. Heating wastewater enhances the diffusion of the ammonia molecules to the surface of the solution, and then to the atmosphere [31]. In the case of air stripping, the $\mathrm{NH}_{3}$ transfer from wastewater to the air is facilitated by the air bubbles. Besides the $\mathrm{pH}$ and temperature, the AFR is another important parameter that influences the removal rates (mass transfer) of ammonia from SW, as it establishes a high gradient of ammonia concentration between the liquid and air phases [32,38]. This process is known as 'diffusion': The molecules (free ammonia in this case) spontaneously mix an, moving from regions of relatively high concentration into regions of lower concentration [44], blowing air in the SW. Therefore, the transfer of ammonia from the wastewater is strongly improved by the air flow. The water vapour stripped by the air flow is generally collected into a third unit (condenser), while the gaseous ammonia flows into the last unit (trap), containing an acidic solution (generally $\mathrm{H}_{2} \mathrm{SO}_{4}$ ), where the ammonia nitrogen is recovered as salt.

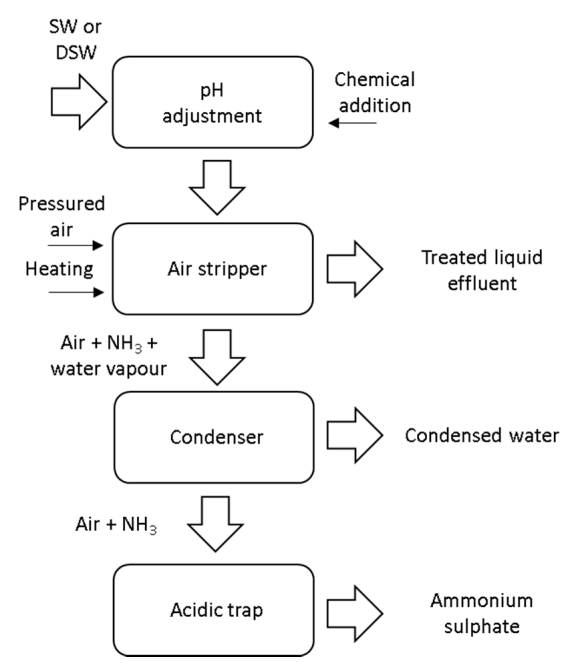

Figure 1. Scheme of the air stripping process and recovery of ammonium sulphate as by-product (SW = swine wastewater; DSW = digested swine wastewater). 
Typical literature values of the parameters influencing air stripping are $\mathrm{pH}$ between 10.0 and 11.0, temperature up to $80^{\circ} \mathrm{C}$, and air flow rate from 0.5 to $10 \mathrm{~L} \mathrm{~L}^{-1} \mathrm{~min}^{-1}$.

\subsection{Processes of Nutrient Recovery and Alternative Schemes of Air Stripping}

Although air stripping theoretically is an efficient method to remove ammonia from wastewater, this process shows some drawbacks, such as the fouling of the ammonia stripping tower, production of sludge, and release of ammonia gas [32]. Fouling of stripping tower is usually due to the to the formation of salts (e.g., calcium carbonate) that scale the surface of the packing materials [32], but also to the presence of suspended solids. The preliminary phase of solid-liquid separation is extremely important to avoid this problem, as most of the suspended solids can be retained in the solid fraction after separation [36]. Moreover, the high cost of the air stripping process may limit its application in the future [4].

Chemicals, such as alkalis for raising up the $\mathrm{pH}$ of the treated wastewater over 9.5, [4] and acids for lowering the $\mathrm{pH}$ of the post-stripping sludge, are needed during air stripping. This need is another issue of the process [27], since alkalis (such as lime, $\mathrm{NaOH}$, or $\left.\mathrm{Ca}(\mathrm{OH})_{2}\right)$ are quite cheap, but high doses can increase the overall cost of air stripping [45]. For this reason, the $\mathrm{pH}$ optimisation is advised to balance the efficiency and cost of the process [32]. On the other hand, the effect of the different alkali type on the ammonia removal efficiency is not significant [46]. The $\mathrm{pH}$ adjustment may be necessary to meet the required limits for the disposal of the treated wastewater in sewage or water bodies, thus increasing the treatment costs [32]. The latter can be increased, when pre-heating (in the case of high-temperature process, sometime close to $80^{\circ} \mathrm{C}$ [47]) and/or high aeration rates (up to $10 \mathrm{~L}_{\text {air }}$ $\mathrm{L}_{\text {wastewater }}{ }^{-1} \mathrm{~min}^{-1}$ ) are required, to fasten the process [4].

Besides the process cost, the emission of the stripped ammonia to the atmosphere is a serious environmental issue [32]. For this reason, the ammonia adsorption after air stripping allows its conversion in the form of salt and this prevents the direct release of the ammonia into the environment [32]. This is a sustainable option for the valorisation of nitrogen in wastewater [48], since, as mentioned above, the recovered ammonium sulphate is marketable as fertiliser in agriculture. This option is one of the main advantages of air stripping, as detailed below. However, the ammonia concentration in the wastewater is another important factor affecting air stripping efficiency. In order to ensure a high concentration gradient for ammonia diffusion, aeration should be increased with increasingly high ammonia concentration [31] (thus increasing the energy cost). Air stripping of wastewater with low ammonia concentration (less than $2 \mathrm{~g} \mathrm{~L}^{-1}$ ) is not economically sustainable $[4,29]$. The production of the fertiliser obtained by air stripping (ammonium sulphate) strictly depends on the concentration of ammonia in wastewater (the recovery of the ammonia salt is explained in the following Section 2.2.1). Therefore, a limited production of marketable fertiliser makes the process not economically convenient.

\subsubsection{Ammonium Sulphate Recovery by Air Stripping}

Ammonium sulphate can be simply recovered by an adsorbing unit (acidic trap) immediately after the gas stripping phase $[29,47,49,50]$ (Figure 1). The amount of ammonium sulphate recovered can be determined by the stoichiometric Equation (4):

$$
2 \mathrm{NH}_{3}+\mathrm{H}_{2} \mathrm{SO}_{4} \rightarrow\left(\mathrm{NH}_{4}\right)_{2} \mathrm{SO}_{4}
$$

In this equation, it is hypothesized that the ammonium ions in the wastewater sample are totally converted to ammonia gas. The Gibbs' free energy of formation $\left(\Delta_{\mathrm{f}} \mathrm{G}^{0}\right)$ under standard conditions $\left(\mathrm{pH}=7\right.$ and $\left.25^{\circ} \mathrm{C}\right)$ of the ammonium sulphate is $-596.52 \mathrm{~kJ} \mathrm{~mol}^{-1}$. Since the Gibbs' free energy is negative, the product formation in the Equation (4) is spontaneous. The production of the ammonium sulphate not only allows the recovery of nitrogen, but also makes sulphur available as macronutrient. The products recovered by the acidic trap generally include ammonium sulphate, concentrated 
ammonia solution, or other ammonia salts, such as ammonium nitrate [4]. Ammonium nitrate $\left(\mathrm{NH}_{4} \mathrm{NO}_{3}\right)$ results from the reaction between $\mathrm{NH}_{3}$ and nitric acid and $\mathrm{HNO}_{3}$, [51]), according to the following reaction (Equation (5)) [52]:

$$
\mathrm{NH}_{3}+\mathrm{HNO}_{3} \rightarrow \mathrm{NH}_{4} \mathrm{NO}_{3}
$$

As for the ammonium sulphate, this is a spontaneous reaction $\left(\Delta_{\mathrm{f}} \mathrm{G}^{0}=-53.88 \mathrm{~kJ} \mathrm{~mol}{ }^{-1}\right)$.

High quality and/or purity of these products should be ensured for reaching the market standards [36]. In the case of nitrogen recovery by air stripping, the use of sulphuric acid of high quality is sufficient to recover high purity by-products [36]. The amount of sulphuric acid required affects the $\mathrm{S}$ concentration in the salt; salt $\mathrm{pH}$ can largely vary from about 3.0 to 7.5 [51]. In general, low values of $\mathrm{pH}$ may lead to corrosion of machinery, leaf burning, and soil acidification in case of long-term application [53], while high $\mathrm{pH}$ may cause $\mathrm{NH}_{3}$ volatilisation during the fertilisation [51].

The acidic trap usually consists of a packed tower, in which the acid is sprayed by nozzles over the packing material and ammonia-enriched air is blown into the tower in counter current. At the real scale, the result is a concentrated solution of ammonium sulphate (with salt concentration of about $30 \%)$ marketed as liquid fertiliser at 90 to $120 € \operatorname{ton}^{-1}[36,53,54]$. This price is lower compared to the cost of crystallised ammonium sulphate (about $140 € \operatorname{ton}^{-1}[55,56]$ ), since the market price mainly depends on the particle size of the salt [36,57]. The difficulty to obtain large-sized ammonium sulphate is mainly due to the construction, operational, and maintenance costs of the crystalliser vessel. Producing small-sized (about 0.4-1.0 mm) crystals of ammonium sulphate is more sustainable, compared to higher sizes (up to $2.6 \mathrm{~mm}$ ), in terms of initial capital cost, energy requirement, and plant management [57]. In order to evaluate the purity of the produced ammonium sulphate, some physico-chemical analyses are required. In particular, the melting point of the salt should be equal to $240{ }^{\circ} \mathrm{C}$ and the nitrogen and sulphur content should be equal to $20 \%$ and $24 \%$, respectively [58]. Nitrogen is determined by Kjeldahl method, while sulphur by gravimetric determination. However, ammonium sulphate produced from wastewater may show organic contamination (impurities), which affects the quality and the value as fertiliser [48]. In this case, biofilters can be used as a supplementary treatment to control volatile organic matter presence [38]. On the other hand, impurities (such as aluminium sulphate) were found to increase the crystallisation kinetics and size of the produced ammonium sulphate [59]. This was probably due to the different adsorption equilibria of the impurities on the crystal. Hence, the control of impurity concentrations may lead to the optimisation of crystal size and quality [59]. Also the concentrated ammonia solution (under non-crystallised form) is marketed, because the technical and economic sustainability of ammonium sulphate production under granular form has not been extensively investigated [36]. On the other hand, the higher nitrogen concentration in the salt reduces the transport costs of these products compared to the animal manure [51].

The ammonium sulphate can replace the synthetic fertilisers, since it is rich in nitrogen and sulphur, which are crop macronutrients [36,53]; this compound is particularly recommended for soils with alkaline or neutral reaction [32,35]. However, nitrogen recovery by air stripping or other treatments is more expensive than the production of synthetic ammonia fertiliser. The latter product is obtained by the well-consolidated Haber-Bosch process [4]. The energy requirement of this process is around $10 \mathrm{kWh} \mathrm{kg}^{-1}[50,60]$, which is practically equal to the value of the air stripping process (9 $\mathrm{kWh} \mathrm{kg}^{-1}$ of nitrogen) $[29,49,60]$.

The ammonium sulphate can be recovered from raw wastewater and digestate from anaerobic digestion, thanks to the release of nutrients in soluble form (e.g., $\mathrm{N}-\mathrm{NH}_{4}{ }^{+}, \mathrm{P}_{-} \mathrm{PO}_{4}{ }^{3-}$, and $\mathrm{K}-\mathrm{K}^{+}$) during the anaerobic biodegradation [4]. However, the digestate from animal manure can be subjected to the strict regulation for fertilisers issued by some countries, such as the European Union. Under this point of view, processing of digestate for nutrient recovery can comply with these regulation constraints, and this turns the SW disposal problem into an economic opportunity [36]. It must be pointed out that the utilisation of ammonium sulphate from animal manure is also often officially regulated (e.g., $170 \mathrm{~kg}$ of nitrogen $\mathrm{ha}^{-1} \mathrm{yr}^{-1}$ ) according to the "Nitrate Directive" for the EU's countries (91/676/CEE) [51,61]. 
In the United States, the standards for agricultural waste management are reported in the National Handbook of Conservation Practice Standards (CNMPs) [62], drafted in accordance with the conservation planning policies of the US Natural Resources Conservation Service (NRCS) and the guidance of the Environmental Protection Agency (EPA). Moreover, the following important standards Conservation Practice Standards (CPS), that define the minimum level of quality by which these practices are planned, operated, and maintained, are shown in the Agricultural Waste Management Field Handbook [63]: Nutrient Management (Code 590); Amendments for the Treatment of Agricultural Waste (Code 591); Waste Treatment (Code 629); Waste Utilization (Code 633).

With regards to Latin America, every country establishes its own regulations. For instance, prevention for water pollution in Bolivia is regulated by the Law 1333 [64], while in Argentina, the protection of water quality and control of pollution are regulated by the Decree 674/89 and 776/92. In general, most of the countries of Latin America adopt regulations based on the EPA's guidelines [65].

In Asian countries, e.g., China, the development of intensive farming required supply of nutrients in livestock manure; the uncontrolled discharge of manure waste, including SW, into the environment was facilitated by the diversity of regulations adopted by the different cities [66]. The allowed ammonium concentration discharge is regulated by the Discharge Standard of Water Pollutant for Ammonia Industry (GB 13458-2001) [67,68]. However, economic aspects may limit the diffusion of these technologies [68].

The agronomic effects of the ammonium sulphate produced by air stripping and used as soil fertiliser must be compared to the same product synthesised by the industry. In this regard, the literature complains unsatisfactory results, as more attention has been paid to the recovery technologies [51] than to the quality and agronomic effects of recovered nutrients. Szymanska et al. [69] carried out an experiment in pots on maize and grass in silty loam and loamy sand soils. Compared to soil without fertilisation, these authors found crop yields under the recovered fertiliser $(88 \%$ and $73 \%$ for maize and grass, respectively) that were similar as the yields under the commercial products $(125 \%$ and $94 \%$, respectively) regardless of the type of soil. Similar results were obtained by Sigurnjak et al. [51] in terms of fertilising effects of ammonium sulphate compared to the synthetic nitrogen fertilisers. Moreover, this study showed that the nitrogen in the recovered ammonium sulphate is entirely under the mineral form $\left(100 \%\right.$ as $\left.\mathrm{NH}_{4}{ }^{+}-\mathrm{N}\right)$, such as the synthetic nitrogen fertiliser. The absence of phosphorous in ammonium sulphate can be considered a positive aspect, because the nitrogen requirements of crops can be satisfied without exceeding the phosphorous application rates [51].The results obtained in the literature suggest that the ammonium sulphate recovered in bio-refinery can replace the industrial ammonium sulphate used as fertiliser in crop cultivation with evident economic and environmental benefits $[51,69]$.

\subsubsection{Air Stripping Applications in Literature}

Some applications of air stripping at full scale have been found in the literature (Table 3). The systems shown in Table 3 were applied to different waste streams (such as digestate, industrial wastewater, manure) and with different schemes for ammonia nitrogen recovery. Air stripping columns and packed tower are the most common configurations used for the treatment of air streams (such as acidic gases, alcohols, or solvents). In EU countries, companies propose their own patented systems that are more specifically addressed to the treatment of digestate from anaerobic digestion plant and to the recovery of ammonia as fertiliser. For instance, the AMFER ${ }^{\circledR}$ system has been used as pre-treatment of N-rich manure before the anaerobic digestion, thus increasing the capacity of feeding co-substrates to digesters; RECOV'AMMONIA ${ }^{\mathrm{TM}}$ ensures removal efficiencies over $90 \%$. Nitrogen removal systems in Asian countries (e.g., China) are rarely implemented, in spite of the continuous growth of animal farms (especially chicken) and anaerobic digestion plants for treating manure [70]. 
Table 3. Examples of full-scale applications or constructors of air stripping systems in EU, USA, and Asia.

\begin{tabular}{|c|c|c|c|}
\hline Country & $\begin{array}{l}\text { Constructor/ } \\
\text { Plant Site }\end{array}$ & Type of Wastewater & Systems/Applications \\
\hline \multirow{3}{*}{ USA } & \multirow{3}{*}{ Branch Environmental Corporation [71] } & \multirow[b]{2}{*}{ Industrial wastewater } & Closed loop system \\
\hline & & & $\begin{array}{l}\text { The discharged air is treated with an acid wash to form a salt from the ammonia and the air is } \\
\text { reused in the stripper.Capacities up to } 681 \mathrm{~m}^{3} \mathrm{~h}^{-1} \\
\text { Air Stripping Columns }\end{array}$ \\
\hline & & & $\begin{array}{l}\text { Used for relatively highly volatile organic compounds }(\mathrm{VOC}) \text { in a liquid stream. VOCs evaporate } \\
\text { by flowing and mixing the water using an air flow. } \\
\text { Packed Towers } \\
\begin{array}{c}\text { Used for the absorption of a variety of gases and solvents, such as acidic gas, alcohol and } \\
\text { ammonia. } \\
\text { AMFER }^{\circledR}\end{array}\end{array}$ \\
\hline \multirow[t]{3}{*}{ EU- } & Colsen (The Netherlands) [72] & $\begin{array}{c}\text { Digestate } \\
\text { Manure } \\
\text { Highly polluted wastewater }\end{array}$ & $\begin{array}{l}\text { Nitrogen recovery from waste and wastewater flows with high levels of ammonium. No need of } \\
\text { de-watering or of pre-treatment of the waste flow. It consists of just one process step. } \mathrm{CO}_{2} \text { and } \\
\mathrm{NH}_{3} \text { are successively removed from the substrate in a stripping column. The stripping air is } \\
\text { passed through a gas scrubber, where ammonium sulphate or ammonium nitrate is produced. } \\
\text { ANAStrip }{ }^{\circledR} \text { plant }\end{array}$ \\
\hline & GNS (Röblingen am See, DE) [73] & Digeste & 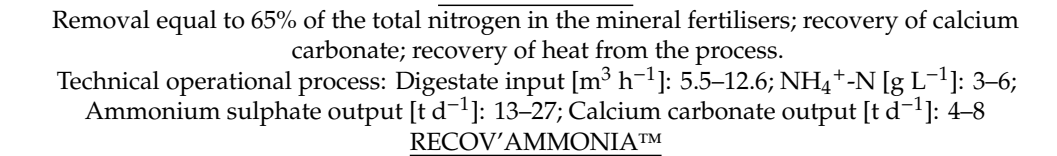 \\
\hline & CMI Europe Environnement (France) [74] & $\begin{array}{c}\text { Digestate } \\
\text { Polluted liquid waste }\end{array}$ & $\begin{array}{l}\text { Removal efficiency: > 92\%; Technical operational process: Pollutants: } \mathrm{NH}_{4}+\text { at } 2,4 \mathrm{~g} \mathrm{~L}^{-1} \text { for a } 102 \\
\mathrm{~kg} \mathrm{~h}^{-1} \text { flow; Liquid flow: } 42 \mathrm{~m}^{3} \mathrm{~h}^{-1} \text { at } 60^{\circ} \mathrm{C} \text { and } \mathrm{pH}=9 \text {; Process gas flow: } 80,000 \mathrm{~m}^{3} \mathrm{~h}^{-1}\end{array}$ \\
\hline Asia & DQY biogas project (Beijing, China) & Raw manure & Recovery of ammonia before anaerobic digestion plant treating 100\% chicken manure [75] \\
\hline
\end{tabular}


Full-scale stripping processes (extensively described in [36]) have been also developed without internal packing. Some of these technologies can even work with relatively high suspended solids or without chemicals addition, giving a higher sustainability under both economic and environmental points of view [36]. The removal efficiency of these systems generally does not exceed 90\% (although they are theoretically designed for a total removal), to reduce the operating costs [36]. On the other hand, a value of $90 \%$ of ammonia reduction in the effluent is generally considered acceptable.

Several experiences with advanced air stripping have been carried out at the laboratory scale, employing schemes and technologies that could be used in future full-scale applications. The volume of the stripping unit at lab-scale ranges from 0.75 to $5 \mathrm{~L}[38,76,77]$. Complex air stripping schemes have been developed, in order to overcome the operational problems previously mentioned and increase the ammonia removal efficiency. For example, the use of vacuum can facilitate the gas stripping [78-80], as vacuum lowers the boiling point of the liquid.

Different schemes have been developed to overcome the fouling problems of the packed towers for large-scale wastewater treatment [27]. A water-sparged aerocyclone was proposed by Quan et al. [43]; the aerocyclone was more efficient compared to the traditional system in terms of energy saving and removal efficiency. A jet loop reactor configuration was used by Degermenci et al. [81] to minimise the aeration energy requirement, since the mass transfer capability of this reactor was higher than other reactor types, even if less air was supplied, due to the high internal mixing and larger contact area. Yuan et al. [82] used a continuous-flow rotating packed bed at lab- and pilot-scale at room temperature; this system was able to maximise the ammonia removal efficiency and reduce the treatment time.

Biological treatments are often used in combination with air stripping (Figure 2). An aerobic treatment was used by Alitalo et al. [83] to increase the $\mathrm{pH}$ of pig slurry without chemical addition, and the combined process removed over $30 \%$ of ammonia. The temperature was in the mesophilic range $\left(35-37^{\circ} \mathrm{C}\right)$ and chemicals $\left(\mathrm{MgO}\right.$ and $\left.\mathrm{Ca}(\mathrm{OH})_{2}\right)$ were added in the subsequent stripping cycles, raising the ammonia removal efficiency up to $86 \%$. Aerobic species generally able to treat swine wastewater are Bacillus amyloliquefaciens, Bacillus cereus, Pseudomonas sp., Paenibacillus sp., and uncultured Actinobacteria bacterium [8]. In a study of Yang et al. [84], the air stripping was used to increase acidogenesis as first stage for the subsequent methanogenesis in a two-stage anaerobic digestion system. In fact, acidogens play the primary role in producing major substrates for methanogens [84].

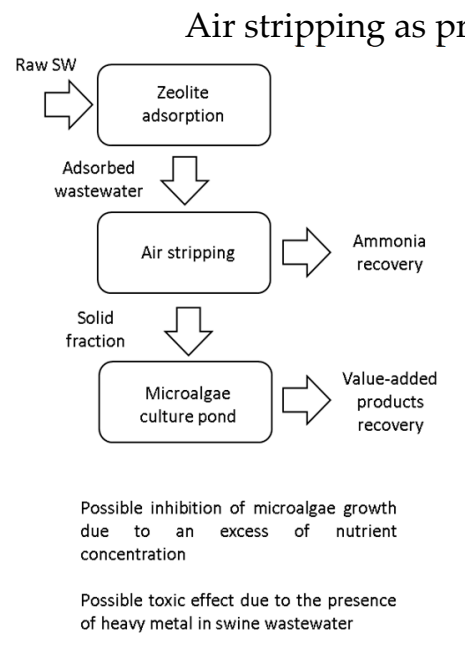

(a)
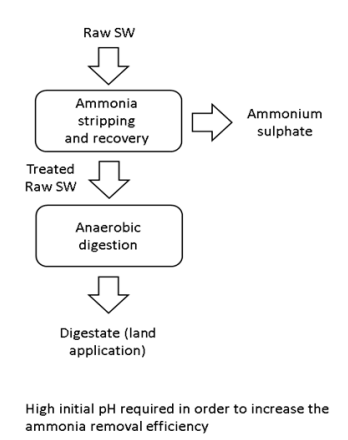

ammonia removal efficiency

Possible inhibitory effect on the subsequent AD process due to a concentration of ions Possible lack of nutrient for anaerobic
microorganisms due to an excess on ammmont microorgan
reduction
Air stripping as post-treatment

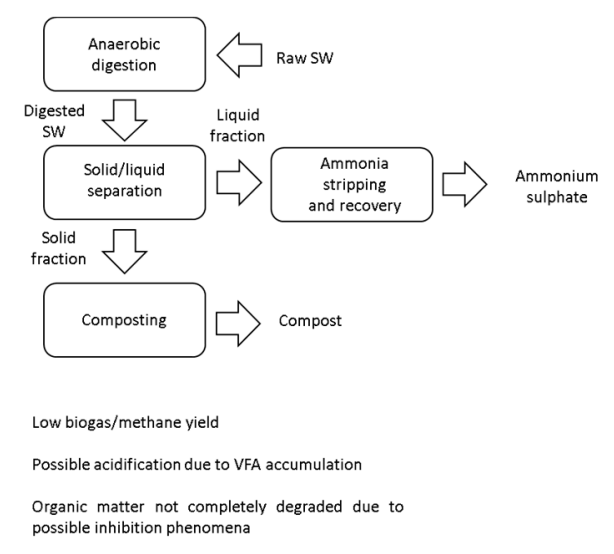

(c)

Figure 2. Schemes and limitations of air stripping (a) coupled with microalgae cultivation system (adapted from Cao et al. [10]), (b) as pre-treatment and (c) as post-treatment of anaerobic digestion $(\mathrm{SW}=$ swine wastewater; $\mathrm{AD}=$ anaerobic digestion $)$. 
Air stripping has been well integrated in bio-energy production systems, as this process can be applied on digestate after biogas production (thus for biofuel and/or heat production) from organic waste or as treatment prior to the anaerobic digestion (Figure 2). As a matter of fact, air stripping enhances methane yield, apart from being cost-effective for ammonia removal [32]. When air stripping is used as pre-treatment of anaerobic digestion, the main purpose is the removal of ammonia compounds that can inhibit the methanogenic activity. In this case, the dose and type of alkalis for initial $\mathrm{pH}$ adjustment of SW should be appropriately evaluated, in order to avoid possible inhibition of the anaerobic digestion due to cationic toxicity [25] or to an excessive nitrogen removal. The anaerobic digestion of raw SW, in addition to the difficulties mentioned above, may lead to the production of a digestate containing organic residues and ammonia compounds. Hence, a further biological (aerated) process is generally required to allow the use of the digestate as soil conditioner. To overcome this issue, air stripping can also be applied as post-treatment of anaerobic digestion to reduce the nitrogen and organic concentrations in the digestate. The stripped ammonia from both configurations (that is, from raw and digested SW) can be recovered as ammonium sulphate.

Moreover, anaerobic digestion is another way to recover carbon (generally expressed in terms of chemical oxygen demand, COD) from swine wastewater, since the biodegradable carbon can be decomposed by microorganisms [85]. However, as previously mentioned, the theoretical methane yield (about $380 \mathrm{~mL} \mathrm{gCOD}^{-1}$, [86] corresponding to a complete conversion of COD), cannot be achieved due to the presence of inhibiting ammonia compounds. When air stripping is coupled with anaerobic digestion (Figure $2 \mathrm{~b}, \mathrm{c}$ ), relatively high temperatures (up to $60^{\circ} \mathrm{C}$ ) can be more easily achieved using the excess heat of the combined heat and power plant [87] or recovering heat from flue gas in conventional schemes of electric generation. The reduction of the area required for the application of nitrogen-rich digestate after the biogas production and the possibility to treat the air stripped digestate in the wastewater plant are other advantages of the combined system AS/AD [41]. The main bacteria in the anaerobic process are hydrogenotrophic Methanocorpusculum, acetoclastic Methanosaeta [88], Methanobacteria, and Methanocorpusculum [89]. Clostridia are generally the most abundant bacteria for hydrolysis and fermentation as they can tolerate high concentrations of volatile fatty acids [89,90], while the Bacilli class easily produces acetate and lactate [88]. Schröder et al. [91] used the liquid fraction of the digestate to recover phosphorous and nitrogen by struvite precipitation; then, the effluent was used for the production of ammonium sulphate by air stripping. These combined systems allowed the nearly total recovery of nutrients. By struvite precipitation, up to $90 \%$ of soluble phosphates was removed, but only less than $30 \%$ of ammonia was recovered [92], due to the equimolar stoichiometry required for the chemical precipitation of struvite [4]. The residual ammonia in soluble form can be potentially recovered by subsequent air stripping.

Struvite (magnesium ammonium phosphate hexahydrate, $\mathrm{MgNH}_{4} \mathrm{PO}_{4}$ ) can be produced by chemical precipitation, which is a common method to recover phosphorous from wastewater. To facilitate the precipitation of struvite, the addition of $\mathrm{Mg}$ compounds (such as $\mathrm{MgO}$ or $\mathrm{MgCl}_{2}$ ) and caustic soda (to increase the $\mathrm{pH}$ up to 10 ) is needed [36]. Struvite precipitates in a 1:1:1 molar ratio following the general equation [92]:

$$
\mathrm{Mg}^{2+}+\mathrm{NH}_{4}^{+}+\mathrm{H}_{n} \mathrm{PO}_{4}^{3-n}+6 \mathrm{H}_{2} \mathrm{O} \rightarrow \mathrm{MgNH}_{4} \cdot 6 \mathrm{H}_{2} \mathrm{O}+n \mathrm{H}^{+}
$$

with $\mathrm{n}=0,1$, or 2 . Gibbs' free energy of formation is about $3060.74 \mathrm{~kJ} \mathrm{~mol}^{-1}$ [93]. By the crystallisation process, over $90 \%$ of the phosphorous in wastewater can be recovered as struvite and approximately half as much nitrogen [94], because struvite contains approximately $0.5 \mathrm{~kg}$ of nitrogen per $\mathrm{kg}$ of phosphorous [35].

The scheme generally used for struvite crystallisation consists of fluidized bed or continuously stirred tank reactors [36]. Stirring facilitates the mixing of the solution and the formation of crystals [92]. However, the presence of other inorganic ions, such as $\mathrm{Ca}^{2+}$ and $\mathrm{CO}_{3}{ }^{2-}$, naturally present in $\mathrm{SW}$, may 
complicate the precipitation of struvite by producing various mineral species [95]. Calcium ions can interact with carbonate ions to form calcite $\left(\mathrm{CaCO}_{3}\right)$ according to the Equation (7) [92]:

$$
\mathrm{Ca}^{2+}+\mathrm{CO}_{3}^{2-} \rightarrow \mathrm{CaCO}_{3}
$$

Gibbs' free energy is equal to $-1129.1 \mathrm{~kJ} \mathrm{~mol}^{-1}$. The chemical composition of struvite derives from its stoichiometric formula and thus its chemical characteristics are always the same. However, its production - with particular regard to purity and cristallisation operation)—is influenced by the process conditions, such as the raw magnesium compounds added (such as $\mathrm{MgO}$ or $\mathrm{MgCl}_{2}$ ), temperature as well as other inorganic ions (e.g., calcium and sodium) and caustic soda present in the alkalis used to increase $\mathrm{pH}$. Microwave radiation technique is also able to improve the ammonia removal during air stripping, by decreasing the reaction time and activation energy. In a study carried out by Ata et al. [77], the ammonia removal efficiency of microwave-assisted air stripping was $25 \%$ higher compared to the conventional heating in air stripping; microwave radiation allows high mass transfer rate of ammonia. Conversely, the effect of aeration was less significant in ammonia removal, while $\mathrm{pH}$, radiation time, and power value strongly affected the overall efficiency of the system [96].

\section{Effect of Air Stripping on Raw SW}

\subsection{Characteristics of Swine Wastewater}

Swine wastewater consists of a mixture of urine, faeces, water spillage, residues of undigested food, antibiotic residues, and pathogenic microorganisms [25,97-99]. Total solids (TS), volatile solids (VS), and chemical oxygen demand (COD) are generally much lower than in raw manure, due to the slurry dilution with washing water [8]. The physico-chemical parameters of SW show large fluctuations (Table 4), mainly due to the variability of the pigpen management practices $[1,7]$. Raw SW is generally alkaline ( $\mathrm{pH}$ of 7.0-7.5), less often slightly acidic. TS content is usually in the range $2-8 \mathrm{~g} \mathrm{~L}^{-1}$, despite some outliers (Table 4). Ammonia nitrogen is generally high $\left(2-10 \mathrm{~g} \mathrm{~L}^{-1}\right)$, while phosphorous content is usually low $\left(0.05-0.13 \mathrm{PO}_{4}{ }^{3-}-\mathrm{P} \mathrm{g} \mathrm{L}^{-1}[28]\right)$. 
Table 4. Summary of the main physico-chemical characteristics of raw swine wastewater (SW) studied in literature.

\begin{tabular}{|c|c|c|c|c|c|c|c|c|c|c|c|c|}
\hline SW & $\begin{array}{l}\mathrm{pH} \\
{[-]}\end{array}$ & $\begin{array}{c}\text { TS } \\
{[\%]}\end{array}$ & $\begin{array}{c}\text { VS } \\
{[\% \mathrm{TS}]}\end{array}$ & $\begin{array}{l}\mathrm{NH}_{4}^{+}-\mathrm{N} \\
{\left[\mathrm{gN} \mathrm{L}^{-1}\right]}\end{array}$ & $\begin{array}{c}\mathrm{NH}_{3}-\mathrm{N} \\
{\left[\mathrm{gN} \mathrm{L}^{-1}\right]}\end{array}$ & $\begin{array}{c}\text { TAN } \\
{\left[\mathrm{gN} \mathrm{L}^{-1}\right]}\end{array}$ & $\begin{array}{c}\mathrm{TN} \\
{\left[\mathrm{gN} \mathrm{L}^{-1}\right]}\end{array}$ & $\begin{array}{l}\mathrm{COD}_{\mathrm{t}} \\
{\left[\mathrm{g} \mathrm{L}^{-1}\right]}\end{array}$ & $\begin{array}{l}\mathrm{COD}_{\mathrm{s}} \\
{\left[\mathrm{g} \mathrm{L}^{-1}\right]}\end{array}$ & $\begin{array}{c}\text { TP } \\
{\left[\mathrm{g} \mathrm{L}^{-1}\right]}\end{array}$ & $\begin{array}{c}\mathrm{PO}_{4}{ }^{--}-\mathrm{P} \\
{\left[\mathrm{g} \mathrm{L}^{-1}\right]}\end{array}$ & Ref. \\
\hline \multirow{24}{*}{ Raw } & $7.4 \pm 0.5$ & - & - & - & - & - & $3.8 \pm 0.2$ & $50.9 \pm 5.5$ & $18.3 \pm 3.0$ & - & - & [100] \\
\hline & $8.0 \pm 0.1$ & $4.2 \pm 0.5 *$ & $2.7 \pm 0.3^{* * * *}$ & - & $2.2 \pm 0.0$ & - & $5.4 \pm 0.0$ & $69.4 \pm 4.2$ & $31.8 \pm 2.4$ & - & - & [101] \\
\hline & $7.7 \pm 0.1$ & $7.9 \pm 0.4 *$ & $5.3 \pm 0.3$ & - & $6.6 \pm 0.1$ & - & $9.4 \pm 0.2$ & $155.5 \pm 9.5$ & $62.4 \pm 5.7$ & - & - & [102] \\
\hline & $7.1 \pm 0.1$ & - & - & $0.892 \pm 0.003$ & - & - & - & - & - & - & - & [103] \\
\hline & $7.2 \pm 0.1$ & - & - & $0.599 \pm 0.006$ & - & - & - & - & - & - & - & [103] \\
\hline & $7.1 \pm 0.0$ & - & - & $0.346 \pm 0.014$ & - & - & - & - & - & - & - & [103] \\
\hline & 7.2 & $18.82 *$ & $14.69 *$ & - & - & - & 6.5 & 181.1 & 19.1 & - & - & [104] \\
\hline & $7.3-7.7$ & - & $0.50-0.52 * * * *$ & $1.8-2.0$ & $0.004-0.01$ & - & - & 10.59313 .220 & $6.129-7.010$ & - & - & [105] \\
\hline & $7.8 \pm 0.4$ & $5.52 \pm 1.47^{*}$ & $3.62 \pm 0.86^{* * * *}$ & $3.6 \pm 1.7$ & - & - & $7.3 \pm 1.9$ & $86.4 \pm 18.6$ & - & - & - & [101] \\
\hline & - & - & - & - & $1.207 \pm 0.111$ & - & $2.023 \pm 0.154$ & $22.929 \pm .889$ & - & $0.358 \pm 0.033$ & - & [97] \\
\hline & - & - & - & - & $0.603 \pm 0.008$ & - & $0.958 \pm 0.005$ & $8.375 \pm 0.152$ & - & $0.216 \pm 0.004$ & - & [9] \\
\hline & 6.18 & $7.21 \pm 0.39$ & $86.39 \pm 0.24$ & $1.021 \pm 0.038$ & - & - & - & $63.724 \pm 6.061$ & - & - & - & [106] \\
\hline & 6.15 & $5.57 \pm 0.66$ & $4.60 \pm 0.66$ & - & - & $1.959 \pm 0.05$ & - & $56.109 \pm 3.794$ & - & - & - & [107] \\
\hline & 7.5 & $5.29^{*}$ & $3.52^{* * * *}$ & $3.39 *$ & - & - & $5.63 *$ & $70.59 *$ & - & - & - & [38] \\
\hline & 6.64 & $5.95 *$ & $3.89 * * *$ & 4.95 & - & - & 7.6 & 94.2 & 54.2 & - & - & [23] \\
\hline & $6.75 \pm 0.18$ & $2.5 \pm 0.18$ & $63.0 \pm 2.28$ & $2.26^{*}$ & - & - & $3.93 *$ & - & - & $0.371 \pm 0.043 *$ & - & [108] \\
\hline & $7.60 \pm 0.15$ & - & - & $0.599 \pm 0.014$ & - & - & $0.798 \pm 0.023$ & $2.383 \pm 0.065$ & - & $0.043 \pm 0.00031$ & - & [10] \\
\hline & $7.3 \pm 0.5$ & $2.04 \pm 0.29 *$ & $1.46 \pm 0.17^{* * * *}$ & $2.7 \pm 0.1$ & - & - & $3.2 \pm 0.12 .7$ & $25.2 \pm 4.1$ & - & - & - & [109] \\
\hline & $8.6 \pm 0.1$ & $37.1 \pm 0.2$ & $77.6 \pm 0.2$ & - & - & $10.6 \pm 0.3 * * *$ & $29.8 \pm 1.5 * * * *$ & - & - & - & - & [110] \\
\hline & 6.64 & 5.95 & $3.89^{* *}$ & - & 4.95 & $\begin{array}{c}10.0 \pm 0.0 \\
-\end{array}$ & 7.6 & 94.2 & 54.2 & - & - & [25] \\
\hline & $7.57 \pm 0.03$ & - & - & $0.612 \pm 0.00814$ & - & - & $0.724 \pm 0.009$ & $4.960 \pm 0.106$ & - & $0.0614 \pm 0.00065$ & - & [76] \\
\hline & $8.11-8.27$ & - & - & $1.013-1.426$ & - & - & $1.381-2.001$ & $5.338-7.065$ & - & $0.0893-0.1894$ & $0.0551-0.1397$ & [28] \\
\hline & $8.02 \pm 0.11$ & - & - & - & $2.74 \pm 0.017$ & - & $3.054 \pm 0.019$ & $23.82 \pm 2.59$ & $10.87 \pm 0.41$ & $0.527 \pm 0.067$ & - & [96] \\
\hline & $7.7 \pm 0.05$ & - & - & - & 2. & $0.730 \pm 0.051$ & - & $3.532 \pm 0.231$ & - & - & - & [111] \\
\hline \multirow{8}{*}{ Filtered } & 7.66 & 0.54 & 55 & 0.993 & - & - & 1.180 & 3.625 & - & - & - & [48] \\
\hline & 7.65 & 1.06 & 55 & 1.298 & - & - & 1.636 & 9.579 & - & - & - & [48] \\
\hline & 7.6 & 5.04 & 70 & 4.197 & - & - & 5.564 & 86.569 & - & - & - & [48] \\
\hline & 7.61 & 5.19 & 61 & 6.708 & - & - & 8.349 & 77.886 & - & - & - & [48] \\
\hline & - & - & - & - & - & 4.0 & - & - & - & - & - & [84] \\
\hline & $7.7 \pm 0.2$ & - & - & - & - & $0.378 \pm 0.024$ & - & $2.756 \pm 0.184$ & - & $0.105 \pm 0.0084$ & - & [112] \\
\hline & $6.6-7.3$ & - & - & $0.400-0.600$ & - & $\begin{array}{c}-0.029 \\
-\end{array}$ & - & $3.500-6.000$ & - & $0.080-0.110$ & - & [98] \\
\hline & - & 3.93 & 73.62 & - & - & - & - & 28.000 & - & - & - & [5] \\
\hline
\end{tabular}

Notes: TS, VS = total and volatile solids, respectively; TAN = total ammonia nitrogen, $\mathrm{TN}=$ total nitrogen; $\mathrm{COD}_{\mathrm{t}}, \mathrm{COD}_{\mathrm{s}}=$ total and soluble chemical oxygen demand, respectively;

$\mathrm{TP}=$ total phosphorous; ${ }^{*}$ adapted data; ${ }^{* *}$ on wet basis; ${ }^{* * *} \mathrm{~g} \mathrm{~kg}^{-1}$ of VS. 
Prior to its direct discharge into the environment or common depuration treatments, SW is generally subjected to physical processes, to reduce its polluting potential.

These physical processes mainly consist of:

- Homogeneous mixing [84,101,102,110,113];

- Solid-liquid separation by settlement $[9,48,103,108]$;

- Sieving and filtration using filters with variable mesh, from $30 \mu \mathrm{m}$ to $8 \mathrm{~mm}$, to remove straw, coarse particles, suspended solids, or large-sized materials (e.g., stones, bedding material) $[5,10,25,48,76,84,98,100,111,112]$.

However, despite these preliminary treatments, SW still contains high concentrations of ammonia compounds and COD, very often over the limits for wastewater disposal [28]. In particular, the ammonia nitrogen is soluble and, as a consequence, its concentration in the liquid fraction may increase after filtration [38]. As mentioned above, the very high concentrations of nitrogen and COD in SW have negative impacts on the environment in the case of disposal without proper treatments.

\subsection{Efficiency of Air Stripping on Raw SW}

A summary of literature data on AS of SW and the related conditions is reported in Table 5, while the ammonia removal efficiency for the different air stripping schemes used for SW is summarised in Figure 3. The effects of the operational parameters of air stripping on the ammonia removal efficiency are highly variable. In general, the highest rates of ammonia removal (over $90 \%$ ) have been found at high temperatures (up to $80^{\circ} \mathrm{C}$ ) and/or $\mathrm{pH}$ (over 10.0) $[38,39,114]$. The control of these parameters, however, makes the treatment expensive, also considering the high reaction time adopted (up to $48 \mathrm{~h}$, [23]). 
Table 5. Literature data about experimental tests of swine wastewater (SW) treatment using air stripping.

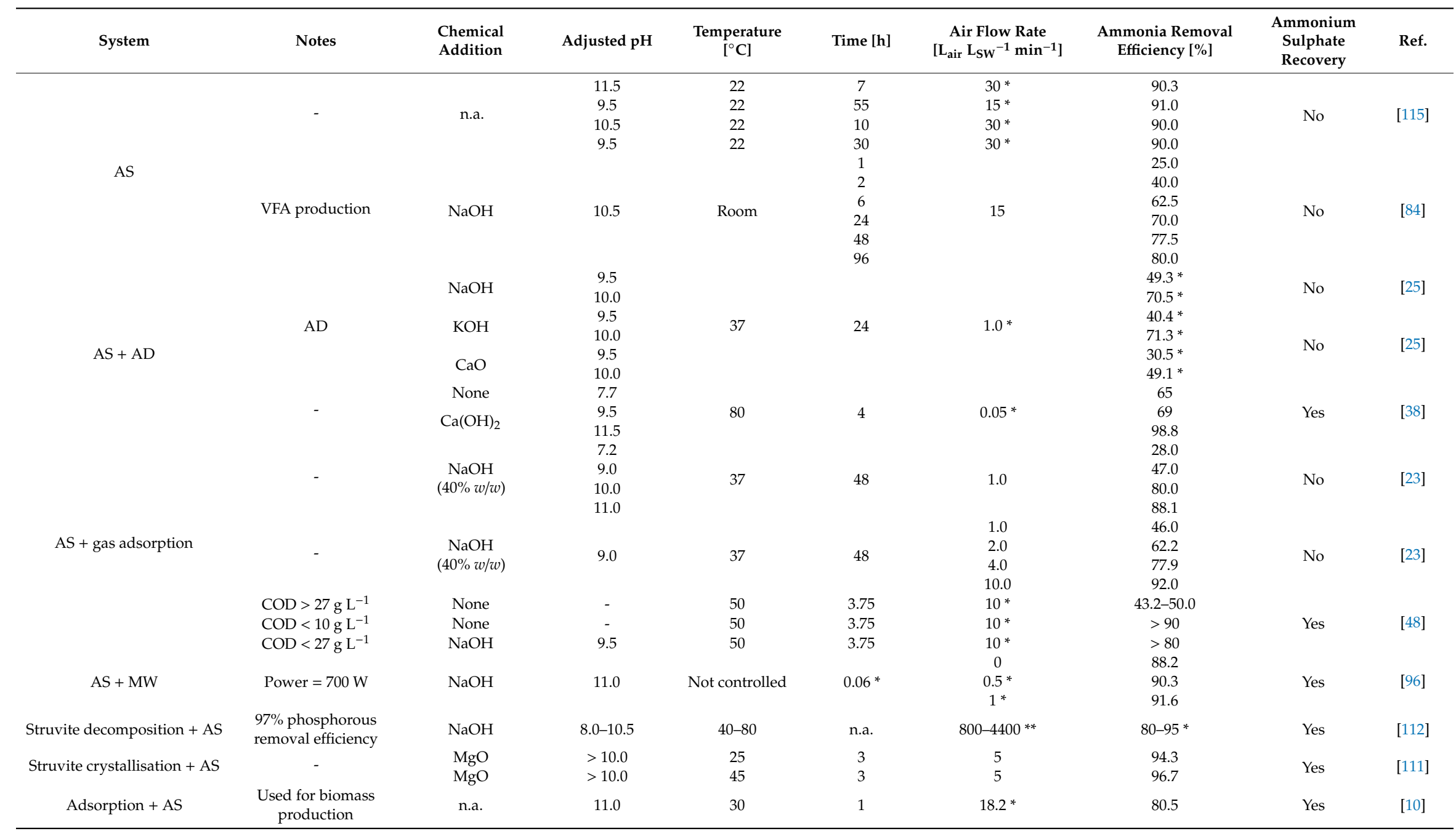

Notes: AS = air stripping; $\mathrm{AD}=$ anaerobic digestion; $\mathrm{MW}=$ microwave radiation; $\mathrm{VFA}=$ very fatty acids; $\mathrm{n} . \mathrm{a} .=$ not available; ${ }^{*}=$ adapted data; ${ }^{* *}=$ gas - liquid volume ratio. 


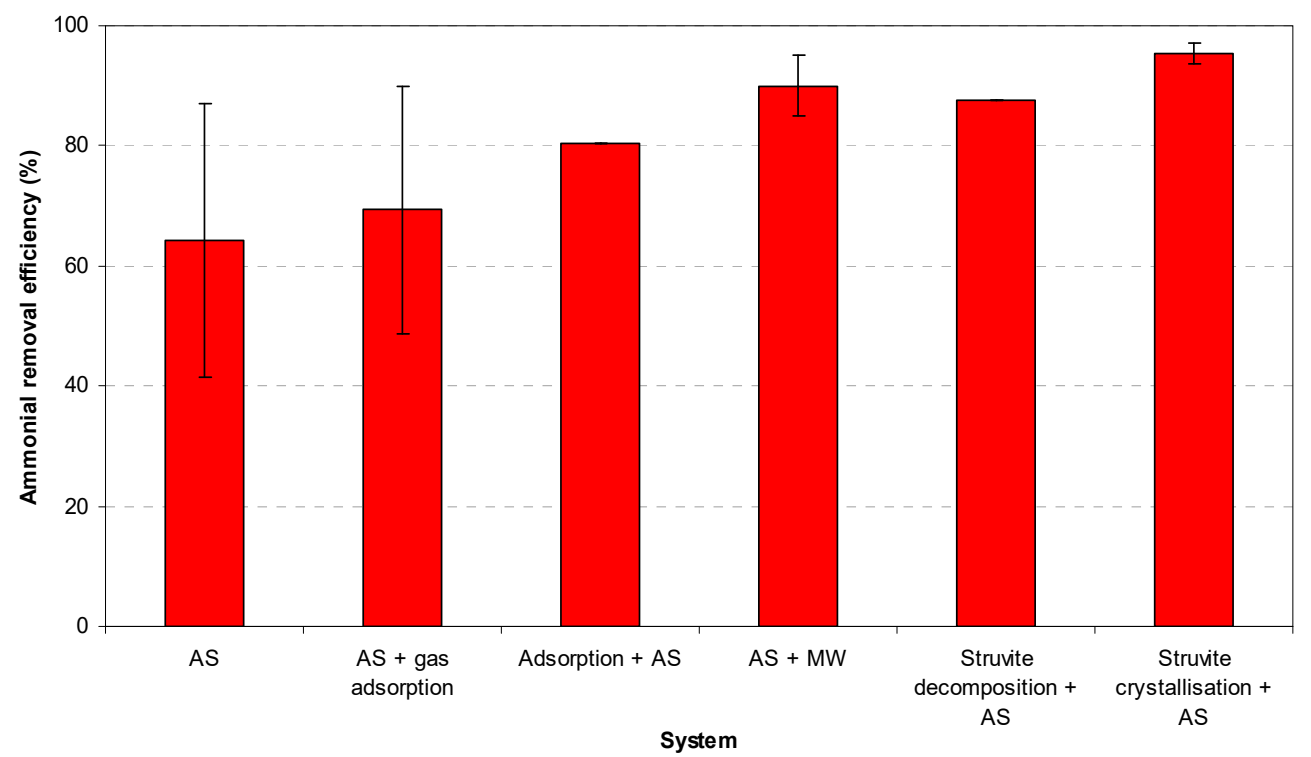

Figure 3. Summary of the ammonia removal efficiency (mean \pm std. dev.) data of the air stripping systems for raw swine wastewater (SW) reported in literature (AS = air stripping; $M W=$ microwave radiation; $\mathrm{AD}=$ anaerobic digestion).

Lime, caustic soda, and calcium hydroxide are commonly used for increasing $\mathrm{pH}$, generally up to 10.0 or even more, since, starting from around 9.3, the dissolved ammonium is quantitatively transformed to ammonia gas [27]. When $\mathrm{pH}$ was increased to 9.5, no significant differences in ammonia removal rates were found by Bonmatí and Flotats [38] compared to the test without $\mathrm{pH}$ control; instead, higher removal efficiencies (in terms of nitrogen and COD) were detected when $\mathrm{pH}$ was corrected to 11.5. At this $\mathrm{pH}$, high ammonia removal can be obtained even at lower temperatures (about $20^{\circ} \mathrm{C}$ ), but operational drawbacks are expected, due to the excess of alkalis [115]. On the other hand, at lower $\mathrm{pH}$ values (typical of raw SW) ammonia can be completely removed, provided that air stripping is carried out at high temperature $\left(80^{\circ} \mathrm{C}\right)$ [38]. The influence of the initial $\mathrm{pH}$ values on ammonia removal efficiency has been also reported by other studies: Zhang and Jahng [25] obtained a removal efficiency of about $70 \%$ at mild temperature $\left(37^{\circ} \mathrm{C}\right)$ and air flow rate $\left(1 \mathrm{~L}_{\text {air }} \mathrm{LSW}^{-1} \mathrm{~min}^{-1}\right)$ and $\mathrm{pH}$ set at 10.0 in $24 \mathrm{~h}$; increasing reaction time to $48 \mathrm{~h}$ and $\mathrm{pH}$ to 11, Zhang et al. [23] showed a removal efficiency of $80 \%$. However, the highest ammonia reduction (92\%) was observed at the highest air flow rate $\left(10 \mathrm{~L}_{\text {air }} \mathrm{LSW}_{\mathrm{SW}}{ }^{-1} \mathrm{~min}^{-1}\right)$ and $\mathrm{pH}$ adjusted to 9.0. These results confirm the influence of the aeration rate on the ammonia removal rate [23]. Moreover, higher $\mathrm{pH}$ values improve the process kinetics, reducing the reaction time needed for a pre-set ammonia removal [48]. Increasing the $\mathrm{pH}$ from the natural value (about 7.0) to 11.0, the rate of ammonia removal increases nearly 8-fold [23]. At $\mathrm{pH}$ over 10.5, the ammonia removal efficiency is directly dependent upon the temperatures of the influent air and liquid [38,115]. At this $\mathrm{pH}$ level (over 10.0) and room temperature, in a study by Yang et al. [84], more than $90 \mathrm{~h}$ were required to achieve $80 \%$ of ammonia removal with a high flow rate $\left(15 \mathrm{~L} \mathrm{~L} \mathrm{~L}^{-1} \mathrm{~min}^{-1}\right)$. Conversely, about $65-70 \%$ of ammonia recovery was obtained at a lower $\mathrm{pH}(7.7-9.5)$ and temperature of $80^{\circ} \mathrm{C}$, using a very low air flow rate $\left(0.05 \mathrm{~L}_{\text {air }} \mathrm{LSW}_{S \mathrm{~min}^{-1}}\right)$ in $4 \mathrm{~h}$ only [38].

The alkali type affects the process efficiency; in particular, sodium and potassium hydroxides allow higher ammonia removal rates compared to lime [25]. The choice of the alkali type is particularly important when air stripping is used as a pre-treatment for SW before AD, as the excess of light metals ions (i.e., $\mathrm{Ca}$ or $\mathrm{Na}$ due to the solubilisation of salts) can inhibit the process. Changes in $\mathrm{pH}$ during air stripping are expected, because the temperature drives the chemical equilibrium among the reagents leading to a $\mathrm{pH}$ modification; for instance, the formation and accumulation of very fatty acids (VFA) can lead to a $\mathrm{pH}$ reduction [38]. Moreover, $\mathrm{pH}$ can increase due to concentration of alkali solution caused by water evaporation [38]. 
As mentioned in Section 2.2.2., air stripping can be integrated with other processes, such as microwave radiation or chemical precipitation for recovering struvite. However, La et a. [96] found that, in the integrated system air stripping plus microwave radiation, the effect of aeration was not significant in the removal efficiency of nitrogen, while the initial $\mathrm{pH}$ of the SW, radiation time, and applied power noticeably influenced this efficiency. Chemical precipitation is more often coupled with air stripping for the simultaneous recovery of nitrogen and phosphorous, allowing a high removal of nutrients. Huang et al. [112] removed over $90 \%$ of total ammonia nitrogen and approximately $97 \%$ of total phosphorous by an integrated reactor. In a study of Huang et al. [111], phosphate was first recovered by chemical precipitation, then the supernatant was subjected to air stripping for ammonia recovery. The best conditions allowing a reduction in ammonia of $94 \%$ in $3 \mathrm{~h}$, consisted of an air flow rate of $5 \mathrm{~L} \mathrm{~L}^{-1} \mathrm{~min}^{-1}$, a dose of $8 \mathrm{~g} \mathrm{~L}^{-1}$ of $\mathrm{MgO}$ for $\mathrm{pH}$ adjustment (over 10.0), and a temperature of $25^{\circ} \mathrm{C}$.

Cao et al. [10] used an adsorbing-stripping stage that efficiently removed nutrients (about $80 \%$ of ammonia) and heavy metals from SW, while obtaining the maximum amount of biomass to obtain various bio-products. The produced biomass was Chlorella vulgaris, an unicellular and autotrophic photosynthetic green algae, which can synthesises lipids, carbohydrates, and protein with water, nitrogen, phosphorus, sun-light, and $\mathrm{CO}_{2}$ through photosynthesis [10]. In this case, air stripping acts as a pre-treatment (Figure 2), since the excessive nutrient concentration in swine wastewater inhibits microalgae growth. In this study, the treatment of SW using the combined system $\mathrm{N}$-adsorption plus air stripping plus microalgae cultivation was proposed as an alternative to the common anaerobic digestion process of raw SW.

Microalgae cultivation would be, indeed, a sustainable technology to recover the carbon from swine wastewater [85]. Microalgae can uptake both inorganic carbon (autotrophic metabolism) in the presence of light or organic carbon (heterotrophic metabolism) when light is absent [85]. A combined system ammonia removal plus anaerobic digestion plus microalgae growth was developed by Zhang et al. [116], with methane and biomass production from the organic matter fed to anaerobic digestion. Several cultivations of microalgae were used for the treatment of SW [85], mainly Chlorella vulgaris [117], Neochloris aquatica CL-M1 [118], Parachlorella kessleri QWY28 [119], Coelastrella sp. QY01 [120], or blooms of Chlorella vulgaris, Scenedesmus obliquus, and Pseudokirchneriella subcapitata with the fungus Ganoderma lucidum [121]. The efficiency in COD reduction was in the range of $63-88 \%$. The removal efficiency as well as the quality of the ammonia solution recovered by air stripping are also influenced by the SW characteristics. More specifically, air stripping of SW with low organic matter $\left(<10 \mathrm{~g}_{\mathrm{COD}} \mathrm{L}^{-1}\right)$ and without $\mathrm{pH}$ modification showed a removal efficiency over $90 \%$, while higher organic matter content $\left(>27.0 \mathrm{~g}_{\mathrm{COD}} \mathrm{L}^{-1}\right.$ ) reduced the nitrogen removal efficiency down to $50 \%$ or less [48]. Increasing $\mathrm{pH}$ to 9.5 significantly improved air stripping with removal efficiencies over $80 \%$ for COD below $40 \mathrm{~g}_{\mathrm{COD}} \mathrm{L}^{-1}$ after a treatment of about $4 \mathrm{~h}$ [48]. The organic compounds stripped from the SW by air stripping could affect the quality of the recovered ammonium sulphate. For this reason, an alkaline trap $(\mathrm{pH}$ of the solution over 12) before the acidic trap can be used to absorb the stripped volatile compounds (retention of over $60 \%$ of the stripped organics) to avoid salt contamination [48].

Although the air stripping is primarily used to remove ammonia compounds, this process is also effective to reduce the organic matter load of wastewater. In the studies reported in Table 3, the COD removal efficiency varied from less than $10 \%$ to $30 \%$. The main reasons of the reduction in organic compounds by air stripping process were the stripping of volatile compounds, such as VFA, and the aerobic biological degradation $[23,25,38]$.

\section{Effect of Air Stripping on Digested SW}

\subsection{Characteristics of Digested SW}

Although being the product of a biochemical treatment (Figure 2c), anaerobically digested SW is still characterised by a high concentration of nitrogen compounds [122,123] (Table 6). In more detail, almost all organic phosphorous and nitrogen in the SW are transformed into phosphate and ammonia 
through the anaerobic process [124], due to the low conversion into biomass compared to the aerobic processes. It follows that, in spite of the biogas production, the anaerobic digestion cannot effectively reduce the nutrient load [125] and especially ammonia accumulates in digesters (usual concentrations range between $300 \mathrm{mg} \mathrm{L}^{-1}$ and $3000 \mathrm{mg} \mathrm{L}^{-1}$ or even more [126]). As a consequence, as happens for raw $S W$, digested SW requires further treatments before its release into the environment $[10,125,127]$ (Figure 2). Air stripping is considered as a more sustainable treatment for digested SW to remove nitrogen compared to other systems, due to (i) the waste heat produced by on-site biogas combustion that is usable to increase the temperature during air stripping, (ii) lower alkali requirement for $\mathrm{pH}$ adjustment, and (iii) more sustainable investment costs $[38,41]$. On the other hand, the digestate stripping is limited by specific constraints, such as the high content of solids, which causes clogging or scaling of the equipment and limits the application of the commonly used packed bed columns [87]. For this reason, digested SW is generally subjected to solid-liquid separation by settling [122] or filtration to remove solids [127], before being processed by air stripping.

\subsection{Efficiency of Air Stripping on Digested SW}

A summary of literature data on air stripping of digested SW and the related process conditions is reported in Table 7, while the ammonia removal efficiency of the different air stripping schemes used for digested SW is summarised in Figure 4. Before discussing the efficiency of the studied systems, it may be worth to mention that the digestate used in the experiments was often derived from the co-digestion of SW with other substrates, such as glycerin, exhausted oil, food processing or slaughterhouse waste [41], pig manure, maize silage, sugar and pig fodder [87], pig excreta and kitchen waste [39], manure, and flushing water of a swine farm [122]. Less commonly, the analysed digested SW derives from the anaerobic digestion of SW only (e.g., [127,128]). 
Table 6. Summary of the main physico-chemical characteristics of digested swine wastewater (SW) studied in literature experiences.

\begin{tabular}{|c|c|c|c|c|c|c|c|c|c|c|c|c|}
\hline $\begin{array}{c}\text { Digestate } \\
\text { Type }\end{array}$ & $\begin{array}{l}\mathrm{pH} \\
{[-]}\end{array}$ & $\begin{array}{l}\text { TS } \\
{[\%]}\end{array}$ & $\begin{array}{c}\text { VS } \\
\text { [\%TS] }\end{array}$ & $\begin{array}{l}\mathrm{NH}_{4}{ }^{+}-\mathrm{N} \\
{\left[\mathrm{gN} \mathrm{L}^{-1}\right]}\end{array}$ & $\begin{array}{c}\mathrm{NH}_{3}-\mathrm{N} \\
{\left[\mathrm{gN} \mathrm{L}^{-1}\right]}\end{array}$ & $\begin{array}{c}\text { TAN } \\
{\left[\mathrm{gN} \mathrm{L}^{-1}\right]}\end{array}$ & $\begin{array}{c}\mathrm{TN} \\
{\left[\mathrm{gN} \mathrm{L}^{-1}\right]}\end{array}$ & $\begin{array}{l}\mathrm{COD}_{\mathrm{t}} \\
{\left[\mathrm{g} \mathrm{L}^{-1}\right]}\end{array}$ & $\begin{array}{l}\mathrm{COD}_{\mathrm{s}} \\
{\left[\mathrm{g} \mathrm{L}^{-1}\right]}\end{array}$ & TP & $\begin{array}{c}\mathrm{PO}_{4}{ }^{3-}-\mathbf{P} \\
{\left[\mathrm{g} \mathrm{L}^{-1}\right]}\end{array}$ & Ref. \\
\hline \multirow{8}{*}{ DSW } & $8.2-8.5$ & - & $0.36-0.42^{* * * *}$ & $2.104-2.111$ & $0.916-0.920$ & - & - & $7.134-7.924$ & $3.138-4.889$ & - & - & [105] \\
\hline & 8.4 & $3.172 *$ & $1.717^{* * * *}$ & $3.68^{*}$ & - & - & $4.73 *$ & - & $41.23 *$ & - & - & [38] \\
\hline & $8.1 \pm 0.08$ & $4.2 \pm 0.44$ & $58.2 \pm 0.89$ & $3.4^{*}$ & - & - & $4.6^{*}$ & - & - & $1.137 \pm 0.355^{*}$ & - & {$[108]$} \\
\hline & 8.17 & 1.48 & 51 & 3.013 & - & - & 3.415 & 14.943 & - & - & - & [48] \\
\hline & 8.75 & 1.13 & 48 & 2.686 & - & - & 3.353 & 9.790 & - & - & - & [48] \\
\hline & $\begin{array}{c}0.70 \\
7.63 \pm 0.04\end{array}$ & $1.149 \pm 0.0724$ * & $0.0461 \pm 0.0012 * * *$ & $0.298 \pm 0.0024$ & - & - & $0.460 \pm 0.0092$ & $1.602 \pm 0.032$ & - & $1.14 .9 \pm 0.00724$ & - & [127] \\
\hline & $7.18 \pm 0.18$ & - & - & $0.706 \pm 0.216$ & - & - & - & $2.108 \pm 0.479$ & - & & $0.0403 \pm 0.0095$ & [124] \\
\hline & $7.3-8.0$ & - & - & - & $>0.160$ & - & - & $0.150-0.500$ & - & $>0.03$ & - & [128] \\
\hline \multirow{3}{*}{ Co-DSW } & $7.76 \pm 0.09$ & - & - & - & - & $0.874 \pm 0.112$ & $0.968 \pm 0.123$ & $1.595 \pm 0.361$ & - & - & - & [122] \\
\hline & 7.94 & 0.070 * & $0.032 * * * *$ & 2.2 & - & - & - & 5.4 & - & - & - & [41] \\
\hline & 7.50 & - & - & 1.510 & 0.034 & - & 1.770 & 2.290 & - & 0.432 & 0.227 & [39] \\
\hline
\end{tabular}

Notes: TS = Total Solids; VS = Volatile Solids; TAN = Total Ammonia Nitrogen; TN = Total Nitrogen; COD, CODt = total and soluble COD; TP = Total Phosphorous; DSW = digested swine wastewater; Co-DSW = Co-Digested swine wastewater.

Table 7. Literature data about experimental tests of digested swine wastewater (SW) treatment using air stripping

\begin{tabular}{|c|c|c|c|c|c|c|c|c|c|}
\hline System & Notes & Chemical Addition & Adjusted $\mathrm{pH}$ & $\begin{array}{c}\text { Temperature } \\
{\left[{ }^{\circ} \mathrm{C}\right]}\end{array}$ & Time $[\mathrm{h}]$ & $\begin{array}{c}\text { Air Flow Rate } \\
{\left[\mathrm{L}_{\text {air }} \mathrm{L}_{\mathrm{Sw}}^{-1} \mathrm{~min}^{-1}\right]} \\
\end{array}$ & $\begin{array}{c}\text { Ammonia Removal } \\
\text { Efficiency [\%] }\end{array}$ & $\begin{array}{l}\text { Ammonium Sulphate/ } \\
\text { Nutrient Recovery }\end{array}$ & Ref. \\
\hline \multirow{10}{*}{ AS } & \multirow{3}{*}{$\begin{array}{l}\text { Continuous bench plant } \\
\text { spraying DSW }\end{array}$} & \multirow{3}{*}{$\mathrm{NaOH}$} & $\begin{array}{c}8.5 \\
10.5\end{array}$ & 50 & \multirow{3}{*}{ n.a. } & $1875^{* * *}$ & $\begin{array}{l}27 \\
93\end{array}$ & \multirow{3}{*}{ Yes } & \multirow{3}{*}[41]{} \\
\hline & & & 10.0 & $\begin{array}{l}30 \\
70\end{array}$ & & $1875^{* * *}$ & $\begin{array}{l}30 \\
92\end{array}$ & & \\
\hline & & & 10.0 & 50 & & $\begin{array}{l}412^{* * *} \\
2100^{* * *}\end{array}$ & $\begin{array}{l}55 \\
88\end{array}$ & & \\
\hline & \multirow{3}{*}{$\underset{\text { purification }}{\mathrm{CO}_{2} \text { stripping }}$} & \multirow{3}{*}{$\mathrm{Ca}(\mathrm{OH})_{2}$} & 12.0 & 15 & 24 & 0 & 25 & \multirow{3}{*}{ Yes } & \multirow{3}{*}[39]{} \\
\hline & & & 12.0 & 15 & 24 & 3 & 72 & & \\
\hline & & & $\begin{array}{l}12.0 \\
12.0\end{array}$ & $\begin{array}{l}15 \\
15\end{array}$ & $\begin{array}{l}12 \\
12\end{array}$ & $\begin{array}{c}5 \\
10\end{array}$ & $\begin{array}{l}90 \\
95\end{array}$ & & \\
\hline & \multirow[t]{2}{*}{$\begin{array}{l}\text { Biogas flow } \\
\text { Flue gas flow }\end{array}$} & \multirow[t]{2}{*}{ None } & $>7.5$ & 65 & 4 & 5 & $\begin{array}{l}47 \\
86\end{array}$ & No & \multirow[t]{2}{*}{ [87] } \\
\hline & & & 10.5 & & 2 & 2000 & 67 & \multirow{3}{*}{ Yes } & \\
\hline & \multirow[t]{2}{*}{ - } & \multirow{2}{*}{$\mathrm{NaOH}$} & 11.0 & 30 & 2 & 2000 & 69 & & \multirow{2}{*}{ [129] } \\
\hline & & & $\begin{array}{l}11.5 \\
120\end{array}$ & 30 & $\begin{array}{l}2 \\
2\end{array}$ & $\begin{array}{l}2000 \\
2000\end{array}$ & $\begin{array}{l}71 \\
74\end{array}$ & & \\
\hline
\end{tabular}


Table 7. Cont.

\begin{tabular}{|c|c|c|c|c|c|c|c|c|c|}
\hline System & Notes & Chemical Addition & Adjusted $\mathrm{pH}$ & $\begin{array}{c}\text { Temperature } \\
{\left[{ }^{\circ} \mathrm{C}\right]}\end{array}$ & Time $[\mathrm{h}]$ & $\begin{array}{c}\text { Air Flow Rate } \\
{\left[\mathrm{L}_{\text {air }} \mathrm{L}_{S W^{-1}} \mathrm{~min}^{-1}\right]} \\
\end{array}$ & $\begin{array}{c}\text { Ammonia Removal } \\
\text { Efficiency [\%] }\end{array}$ & $\begin{array}{c}\text { Ammonium Sulphate/ } \\
\text { Nutrient Recovery }\end{array}$ & Ref. \\
\hline \multirow{4}{*}{ AS + adsorption } & \multirow{3}{*}{ Filtration before AS } & None & 8.5 & \multirow{3}{*}{80} & 5 & \multirow{3}{*}{$0.05 *$} & $>96$ & \multirow{3}{*}{ Yes } & \multirow{3}{*}{ [38] } \\
\hline & & \multirow{2}{*}{$\mathrm{Ca}(\mathrm{OH})_{2}$} & 9.5 & & 4 & & $>96$ & & \\
\hline & & & 11.5 & & 4 & & $>96$ & & \\
\hline & $\mathrm{COD}<10 \mathrm{~g} \mathrm{~L}^{-1}$ & NoneNaOH & $>8.0$ & 50 & 3.75 & $10 *$ & $>90$ & Yes & \multirow{2}{*}{ [48] } \\
\hline \multirow{2}{*}{ AS + struvite } & \multirow[b]{2}{*}{ Simultonous romoulof $\mathrm{P}$} & $\mathrm{MgO}$ & $9-10$ & $\begin{array}{l}50 \\
40\end{array}$ & $\begin{array}{l}3.75 \\
3\end{array}$ & $\begin{array}{l}10^{*} \\
8\end{array}$ & $\begin{array}{l}>90 \\
88 * *\end{array}$ & \multirow{2}{*}{ Yes } & \\
\hline & & $\mathrm{Ca}(\mathrm{OH})_{2}$ & $>11.0$ & $28-30$ & 1 & $13 * * * * *$ & 94 & & [127] \\
\hline \multirow[t]{2}{*}{ Chemical precipitation + AS } & $\begin{array}{l}\text { Simultaneous removal of N,P } \\
\text { and COD by a WSA }\end{array}$ & $\mathrm{Ca}(\mathrm{OH})_{2}$ & $>11.0$ & $28-30$ & 1 & $39 * * * * *$ & $>92$ & \multirow[t]{2}{*}{ Yes } & \multirow[t]{2}{*}{ [128] } \\
\hline & & $\mathrm{Ca}(\mathrm{OH})_{2}$ & $>11.0$ & $28-30$ & 1 & $9 *, * * *$ & $>92 *$ & & \\
\hline Struvite crystallization + AS & $\mathrm{CO}_{2}$ stripping- $\mathrm{SBR}$ & None & - & $0-20$ & $1-4$ & $0.25 *$ & $40-90$ & \multirow{2}{*}{ Yes } & \multirow{2}{*}{ [124] } \\
\hline \multirow[b]{2}{*}{$\mathrm{AS}+\mathrm{MBR}$} & & None & - & $0-30$ & - & $\begin{array}{c}0.42^{*} \\
2800^{* * * *}\end{array}$ & $40-90$ & & \\
\hline & Continuous process & $\mathrm{NaOH}$ & $\begin{array}{c}10.0-10.5 \\
9.0-9.5\end{array}$ & $\begin{array}{l}30 \\
30\end{array}$ & $\begin{array}{l}\text { n.a. } \\
\text { n.a. }\end{array}$ & $\begin{array}{l}2800^{* * * *} \\
2800^{* * *}\end{array}$ & $\begin{array}{l}83 \\
65\end{array}$ & No & [122] \\
\hline
\end{tabular}

Notes: * Adapted/extrapolated data; ${ }^{* *}$ Ammonium recovery in phosphoric acid and struvite precipitation; $* * *$ air to liquid ratio $\left[\mathrm{L}_{\mathrm{air}} \mathrm{min}^{-1}: \mathrm{LDSW}_{\mathrm{DSin}}{ }^{-1}\right.$ or $\left.\mathrm{m} \mathrm{sec}{ }^{-1}: \mathrm{m} \mathrm{sec}{ }^{-1}\right] ; \mathrm{AS}=$ air stripping; WSA = water sperged aerocyclone; $\mathrm{SBR}=$ sequencing batch reactor; $\mathrm{MBR}=$ membrane bioreactor; $\mathrm{DSW}=$ digested swine wastewater; $\mathrm{HRT}=$ hydraulic retention time. 


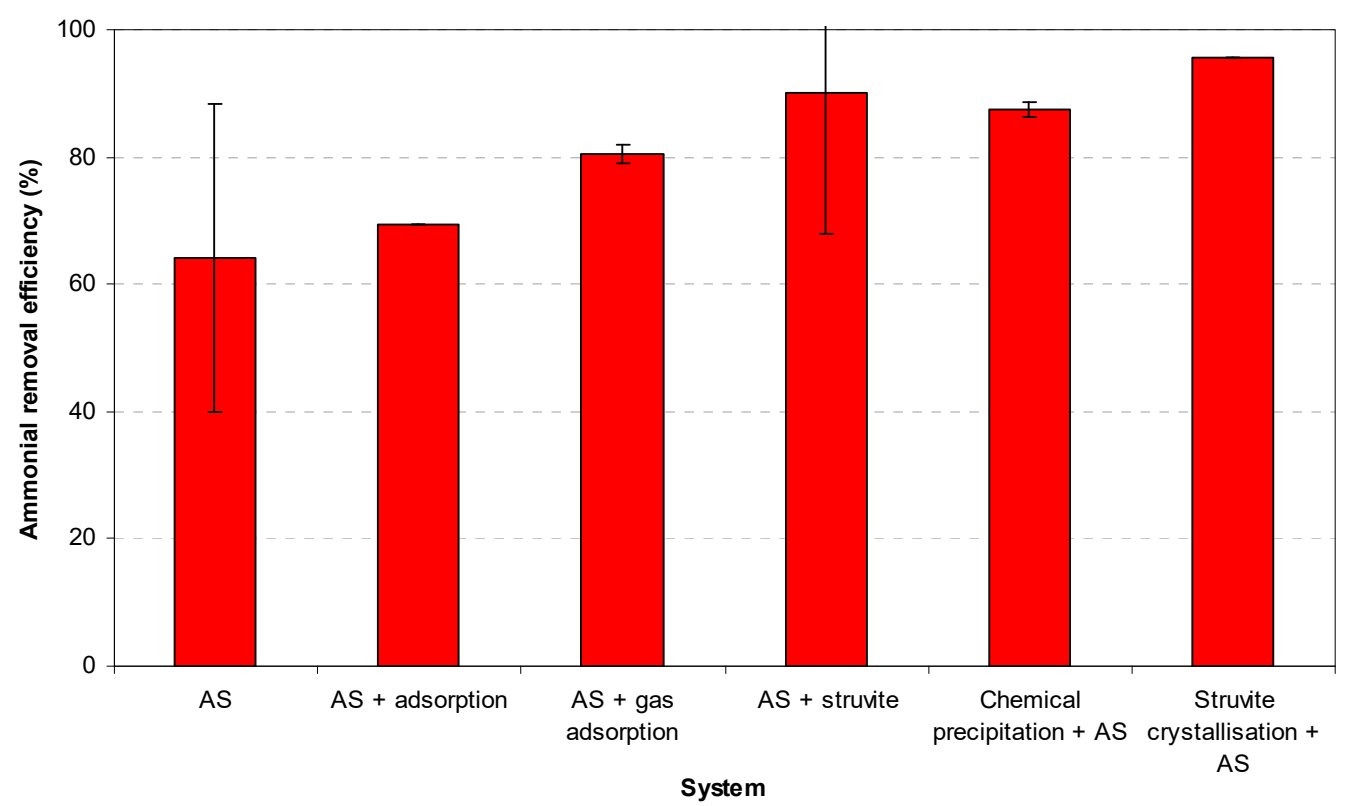

Figure 4. Summary of the ammonia removal efficiency (mean \pm std. dev.) of the air stripping systems for digested swine wastewater (SW) reported in literature (AS = air stripping; $M B R=$ membrane bioreactor).

The effects of air stripping on digested SW are different from those observed in raw SW. In general, a lower reaction time (less than $24 \mathrm{~h}$ ) was required to achieve a higher ammonia removal efficiency (over 90\%); moreover, $\mathrm{pH}$ seems to influence less the overall treatment efficiency, although higher $\mathrm{pH}$ values were effective in improving the process kinetics [48].

An almost complete ammonia removal was achieved by Bonmatí and Flotats [38], by setting the initial $\mathrm{pH}$ at 9.5, but no further increases were reported when the initial $\mathrm{pH}$ was set at 11.5. This showed that, at a temperature of $80^{\circ} \mathrm{C}$, the process requires a $\mathrm{pH}$ higher than 9.5. Lowering the temperature at $50{ }^{\circ} \mathrm{C}$ leads to an ammonia removal of $75 \%$ [41]. Similar results were found by Hidalgo et al. [45], who reported that a $\mathrm{pH}$ over $10.5 \mathrm{did}$ not affect the balance between molecular ammonia and ionic ammonium [32]. Conversely, Guštin and Marinšek-Logar [41] reported that $\mathrm{pH}$ had the strongest effect on stripping, with an ammonium removal up to $93 \%$, while the temperature had the least significant effect. In general, the $\mathrm{pH}$ adjustments in the chemical treatments increases the alkalinity of digested SW (over 9.0-10.0), which requires further treatments before disposal or reuse, such as extensive depuration (e.g., lagooning) or neutralisation.

Lei et al. [39] obtained similar results ( $95 \%$ of removal efficiency) at room temperature, but adopting very high $\mathrm{pH}$ (up to 12.0) and AFR (up to $10 \mathrm{~L}_{\mathrm{air}} \mathrm{L}_{\mathrm{SW}}{ }^{-1} \mathrm{~min}^{-1}$ for $12 \mathrm{~h}$ ). These results indicate that, at the same $\mathrm{pH}$ conditions, the ammonia removal increases with the AFR. However, a lower AFR (e.g., 1 or $5 \mathrm{~L}_{\text {air }} \mathrm{L}_{\mathrm{SW}}{ }^{-1} \mathrm{~min}^{-1}$ ) still ensured high removal efficiencies (up to $90 \%$ ), resulting in a more feasible process [32,39]. The same conclusions were reported by Guštin and Marinšek-Logar [41], who did not observe any increases in ammonia removal efficiency raising the air-to-liquid ratio from 1875 up to 2100 .

Struvite precipitation is the most used physico-chemical process in combination with air stripping for the simultaneous removal of ammonia nitrogen and phosphate from digested SW (as for raw SW, see Section 3.2). Cao et al. [127] used $\mathrm{MgO}$ as chemical additive for both struvite precipitation and $\mathrm{pH}$ adjustment for air stripping of the residual ammonia. The optimal process conditions, allowing an ammonia removal efficiency of about $90 \%$, were a temperature of $40{ }^{\circ} \mathrm{C}$, an AFR of $8 \mathrm{~L} \mathrm{~L}^{-1} \mathrm{~min}^{-1}$, a reaction time of $3 \mathrm{~h}$, and a dose of $\mathrm{MgO}$ equal to $0.75 \mathrm{~g} \mathrm{~L}^{-1}$. Quan et al. [128] used a water-sparged aerocyclone reactor for air stripping after struvite precipitation. $\mathrm{Ca}(\mathrm{OH})_{2}$ was used as precipitant for $\mathrm{NH}_{4}{ }^{+}, \mathrm{PO}_{4}{ }^{3-}$, and organic phosphorous compounds and as $\mathrm{pH}$ conditioner for the air stripping of 
residual ammonia; an ammonia removal over $90 \%$ was achieved in less than $3 \mathrm{~h}$. Another air stripping system used in combination with a membrane bioreactor allowed a nitrogen removal from digested SW higher than $80 \%$ [122].

In order to avoid or at least reduce the need for chemicals as much as possible, a method to adjust $\mathrm{pH}$ may be the use of the biogas and/or the flue gas derived from biogas combustion. Before air stripping, the $\mathrm{pH}$ of water increases, when the amount of $\mathrm{CO}_{2}$ dissolved in the wastewater decreases. Therefore, Lei et al. [39] increased the $\mathrm{pH}$ of the digested effluent (from 7.4 up to 9.3) by $\mathrm{CO}_{2}$ stripping (at the rate of $2.5 \mathrm{~L}_{\mathrm{air}} \mathrm{LDSW}^{-1} \mathrm{~min}^{-1}$ for one day), thus reducing the required dose of alkalis. After air stripping, the effluent was subjected to biogas injection, in order to decrease the $\mathrm{pH}$ of the treated digested SW for the subsequent biological treatment or the disposal into water bodies, and at the same time to purify the biogas. The $\mathrm{pH}$ of the effluent was reduced from 11.0 to $7.0 \mathrm{in}$ less than $0.5 \mathrm{~h}$ (biogas flow rate equal to $1 \mathrm{~L} \mathrm{~L}^{-1} \mathrm{~min}^{-1}$ ) and the methane content in the biogas was increased up to about $75 \%$. Song et al. [124] recovered up to $85 \%$ of phosphate as struvite and removed up to $90 \%$ of ammonia nitrogen by air stripping without adding any chemicals, as the wastewater $\mathrm{pH}$ was increased by $\mathrm{CO}_{2}$ stripping. Moreover, Bousek et al. [87] found that the flue gas (on average $82 \%$ of nitrogen and $18 \%$ of carbon dioxide) cannot replace the air in air stripping, since the ammonia removal efficiency was lower than $50 \%$ compared to a value of $86 \%$ using air. As for raw SW, Laureni et al. [48] evaluated the quality of the ammonium sulphate solution from air stripping of digested SW. It was found that, although the total organic carbon concentrations were below the detection limit, the organic matter contamination of the solution strongly depends on the initial organic matter content and $\mathrm{pH}$. It was suggested that a higher $\mathrm{pH}$ could also limit the contamination of the recovered product. Air stripping of digested SW with an initial organic matter content below $10 \mathrm{~g}_{\mathrm{COD}} \mathrm{L}^{-1}$ showed over $90 \%$ of ammonia removal (in less than $4 \mathrm{~h}$ at an initial $\mathrm{pH}$ of 9.5 [48]).

The COD reduction in digested SW after air stripping was in the range $20-70 \%$ according to the studies of Bonmatí and Flotats [38], Quan et al. [128], and Cao et al. [127]. In the study of Bonmatí and Flotats [38], the high removal of organic matter may be attributed to the high biomass content in the digested SW, which can adsorb suspended solids, subsequently removed by filtration.

\section{Future Perspectives}

Air stripping of raw and digested swine wastewater can be well integrated in the concept of bio-refinery, because this system allows a more sustainable management of the piggery effluent by turning wastewater into new added-value compounds, by-products, and/or bioenergy. Moreover, the combination of air stripping with other technologies seems to be sustainable from both the environmental and economic aspects. The common combined systems include struvite precipitation and air stripping as pre- or post-treatment of the anaerobic digestion. Less commonly, air stripping was used in combination with biomass (e.g., microalgae) production.

The recovery of phosphorous by chemical precipitation of struvite, and the subsequent production of ammonia salts by air stripping is a sustainable option for the recovery of both nutrients, although usually phosphorus concentration in swine wastewater is moderate. Regarding the anaerobic digestion, the application of the air stripping as pre-treatment can increase the methane yield by reducing the inhibitory ammonia compounds. When applied on the digestate (as post-treatment of the anaerobic digestion), the recovery of nitrogen makes the digestate more suitable for direct land application; however, this opportunity needs a deeper insight. A possible solution could be the recovery of both struvite (before the anaerobic digestion) and nitrogen (on the struvite-pretreated swine wastewater subjected to anaerobic digestion). However, many other solutions can be developed since air stripping offers flexible and simple opportunities of implementation.

Beside the common parameters ( $\mathrm{pH}$, temperature, and air flow rate), the presence of organic matter of swine wastewater plays an important role on ammonia removal efficiency (for both raw and digested swine wastewater). However, the influence of the organic matter on this process has not been extensively studied. Thus, further research should evaluate the impact of the stripped organic volatile 
compounds on the quality of the ammonia salt produced by the air stripping as well as the agronomic effects of land application of the recovered by-products as fertilisers.

Overall, this review has demonstrated that the air stripping process as a treatment of raw and digested swine wastewater has not been exhaustively investigated. For instance, few experiments were found on the coupled system air stripping-biomass growth and optimized air stripping-anaerobic digestion as well as on the use of other technologies (e.g., microwave radiation). The possible nutrient recovery and biomass harvest (to obtain energy or by-products) would be of great interest on a circular economy approach. Under this aspect, a special effort is required to demonstrate the overall competitiveness on the market of fertilisers of the recovered ammonia salts.

\section{Conclusions}

This review has analysed and summarised the main studies of air stripping carried out on raw and digested swine wastewater. The related experiments were performed under a large variety of operational conditions: Natural (uncontrolled) or adjusted $\mathrm{pH}$ (up to 12), room temperature or wastewater heating up $80^{\circ} \mathrm{C}$, air flow rate from 0.5 to $10 \mathrm{~L} \mathrm{~L}^{-1} \mathrm{~min}^{-1}$, and initial ammonia content from 1.0 to $7.0 \mathrm{~g} \mathrm{~L}^{-1}$. The combination of these environmental conditions led to ammonia removal efficiencies from about $20 \%$ to nearly $100 \%$. These results and the comparisons of literature experiences on raw (Section 3.2) and digested (Section 4.2) swine wastewater suggested the following indications, which could help the optimization of the air stripping treatment. The initial $\mathrm{pH}$ value of the wastewater before air stripping is the most influencing parameter, whose optimal value (9.5-10.0) allows an efficient and quick ammonia removal. At $\mathrm{pH}$ under 9.5, temperatures over $50{ }^{\circ} \mathrm{C}$ and/or air flow rates up to $5 \mathrm{~L}_{\text {air }} \mathrm{LSW}^{-1} \mathrm{~min}^{-1}$ are needed for an efficient process. An excess of alkali, although causing drawbacks (e.g., membrane fouling), noticeably reduce the costs of aeration and heating. Moreover, no $\mathrm{pH}$ adjustment of the air stripping treated wastewater is needed when anaerobic digestion follows air stripping, since the $\mathrm{pH}$ of the pre-treated wastewater is generally optimal for an efficient anaerobic digestion. Digested swine wastewater is instead less influenced by the initial $\mathrm{pH}$ value.

Author Contributions: Conceptualization, P.S.C. and D.A.Z.; methodology, P.S.C. and D.A.Z.; formal analysis, P.S.C. and D.A.Z.; data curation, A.F.; writing — original draft preparation, A.F.; writing-review and editing, A.F., P.S.C., and D.A.Z.; supervision, P.S.C. and D.A.Z. All authors have read and agreed to the published version of the manuscript.

Funding: This research received no external funding.

Conflicts of Interest: The authors declare no conflict of interest.

\section{References}

1. Kim, J.-H.; Chen, M.; Kishida, N.; Sudo, R. Integrated real-time control strategy for nitrogen removal in swine wastewater treatment using sequencing batch reactors. Water Res. 2004, 38, 3340-3348. [CrossRef]

2. Hill, V.R. Prospects for pathogen reductions in livestock wastewaters: A review. Crit. Rev. Environ. Sci. Technol. 2003, 33, 187-235. [CrossRef]

3. Mores, R.; Treichel, H.; Augusto, C.; Kunz, A.; Steffens, J.; Marcos, R. Remove of phosphorous and turbidity of swine wastewater using electrocoagulation under continuous flow. Sep. Purif. Technol. 2016, 171, 112-117. [CrossRef]

4. Mehta, C.M.; Khunjar, W.O.; Nguyen, V.; Tait, S.; Batstone, D.J. Technologies to recover nutrients from waste streams: A critical review. Crit. Rev. Environ. Sci. Technol. 2015, 45, 385-427. [CrossRef]

5. Safavi, S.M.; Unnthorsson, R. Enhanced methane production from pig slurry with pulsed electric field pre-treatment. Environ. Technol. 2017, 3330, 1-11. [CrossRef]

6. Motteran, F.; Pereira, E.L.; Campos, C.M.M. The behaviour of an anaerobic baffled reactor (ABR) as the first stage in the biological treatment of hog farming effluent. Braz. J. Chem. Eng. 2013, 30, 299-310. [CrossRef]

7. Cheng, N.; Lo, K.V.; Yip, K.H. Swine wastewater treatment in a two stage sequencing batch reactor using real-time control. J. Environ. Sci. Heal.-Part B Pestic. Food Contam. Agric. Wastes 2000, 35, 379-398. [CrossRef] 
8. Cai, J.; Mo, X.; Cheng, G.; Du, D. Pretreatment of piggery wastewater by a stable constructed microbial consortium for improving the methane production. Water Sci. Technol. 2015, 71, 769-776. [CrossRef]

9. Yang, D.; Deng, L.; Zheng, D.; Wang, L.; Liu, Y. Separation of swine wastewater into different concentration fractions and its contribution to combined anaerobic-aerobic process. J. Environ. Manag. 2016, 168, 87-93. [CrossRef]

10. Cao, L.; Zhou, T.; Li, Z.; Wang, J.; Tang, J.; Ruan, R.; Liu, Y. Effect of combining adsorption-stripping treatment with acidification on the growth of Chlorella vulgaris and nutrient removal from swine wastewater. Bioresour. Technol. 2018, 263, 10-16. [CrossRef]

11. De Haas, D.W.; Wentzel, M.C.; Ekama, G.A. The use of simultaneous chemical precipitation in modified activated sludge systems exhibiting biological excess phosphate removal. Part 1: Literature review. Water SA 2001, 27, 151-165.

12. Liu, Y.; Shi, H.; Li, W.; Hou, Y.; He, M. Inhibition of chemical dose in biological phosphorus and nitrogen removal in simultaneous chemical precipitation for phosphorus removal. Bioresour. Technol. 2011, 102, 4008-4012. [CrossRef] [PubMed]

13. Cox, A.E.; Camberato, J.J.; Smith, B.R. Phosphate availability and inorganic transformation in an alum sludge-affected soil. J. Environ. Qual. 1997, 26, 1393-1398. [CrossRef]

14. Loughrin, J.H.; Quintanar, A.I.; Cook, K.L.; Lovanh, N.C.; Lane, B. Seasonal variation in heat fluxes, predicted emissions of malodorants, and wastewater quality of an anaerobic swine waste lagoon. Water Air Soil Pollut. 2012, 223, 3611-3618. [CrossRef]

15. Trias, M.; Hu, Z.; Mortula, M.M.; Gordon, R.J.; Gagnon, G.A. Impact of seasonal variation on treatment of swine wastewater. Environ. Technol. 2004, 25, 775-781. [CrossRef] [PubMed]

16. Craggs, R.A.; Park, J.A.; Heubeck, S.A. Methane emissions from anaerobic ponds on a piggery and a dairy farm in New Zealand. Aust. J. Exp. Agric. 2008, 48, 142-146. [CrossRef]

17. Zema, D.A.; Andiloro, S.; Bombino, G.; Tamburino, V.; Sidari, R.; Caridi, A. Depuration in aerated ponds of citrus processing wastewater with a high concentration of essential oils. Environ. Technol. 2012, 33, 1255-1260. [CrossRef]

18. Andiloro, S.; Bombino, G.; Tamburino, V.; Zema, D.A.; Zimbone, S.M. Aerated lagooning of agro-industrial wastewater: Depuration performance and energy requirements. J. Agric. Eng. 2013, 44, 827-832. [CrossRef]

19. Zema, D.A.; Andiloro, S.; Bombino, G.; Caridi, A.; Sidari, R.; Tamburino, V. Comparing different schemes of agricultural wastewater lagooning: Depuration performance and microbiological characteristics. Water Air Soil Pollut. 2016, 439, 227-439. [CrossRef]

20. Calabrò, P.S.; Fòlino, A.; Tamburino, V.; Zappia, G.; Zema, D.A. Increasing the tolerance to polyphenols of the anaerobic digestion of olive wastewater through microbial adaptation. Biosyst. Eng. 2018, 172, $19-28$. [CrossRef]

21. Zema, D.A.; Fòlino, A.; Zappia, G.; Calabrò, P.S.; Tamburino, V.; Zimbone, S.M. Anaerobic digestion of orange peel in a semi-continuous pilot plant: An environmentally sound way of citrus waste management in agro-ecosystems. Sci. Total Environ. 2018, 630. [CrossRef]

22. Zema, D.A.; Calabro, P.S.; Folino, A.; Tamburino, V.; Zappia, G.; Zimbone, S.M. Wastewater management in citrus processing industries: An overview of advantages and limits. Water 2019, 11, 2481. [CrossRef]

23. Zhang, L.; Lee, J.W.; Jahng, D. Ammonia stripping for enhanced biomethanization of piggery wastewater. J. Hazard. Mater. 2012, 199-200, 36-42. [CrossRef] [PubMed]

24. Hansen, K.H.; Angelidaki, I.; Ahring, B.K. Anaerobic digestion of swine manure: Inhibition by ammonia. Water Res. 1998, 32, 5-12. [CrossRef]

25. Zhang, L.; Jahng, D. Enhanced anaerobic digestion of piggery wastewater by ammonia stripping: Effects of alkali types. J. Hazard. Mater. 2010, 182, 536-543. [CrossRef] [PubMed]

26. Browne, J.D.; Allen, E.; Murphy, J.D. Evaluation of the biomethane potential from multiple waste streams for a proposed community scale anaerobic digester. Environ. Technol. (United Kingdom) 2013, 34, 2027-2038. [CrossRef] [PubMed]

27. Sengupta, S.; Nawaz, T.; Beaudry, J. Nitrogen and Phosphorus Recovery from Wastewater. Curr. Pollut. Rep. 2015, 1, 155-166. [CrossRef]

28. Zhang, D.; Chen, Y.; Jilani, G.; Wu, W.; Liu, W.; Han, Z. Optimization of struvite crystallization protocol for pretreating the swine wastewater and its impact on subsequent anaerobic biodegradation of pollutants. Bioresour. Technol. 2012, 116, 386-395. [CrossRef] 
29. Perera, M.K.; Englehardt, J.D.; Dvorak, A.C. Technologies for recovering nutrients from wastewater: A critical review. Environ. Eng. Sci. 2019, 36, 511-529. [CrossRef]

30. Sagberg, P.; Berg, K.G. Cost optimisation of nitrogen removal in a compact nitrogen and phosphorus WWTP. Water Sci. Technol. 2000, 41, 147-154. [CrossRef]

31. Karri, R.R.; Sahu, J.N.; Chimmiri, V. Critical review of abatement of ammonia from wastewater. J. Mol. Liq. 2018, 261, 21-31. [CrossRef]

32. Kinidi, L.; Tan, I.A.W.; Binti, N.; Wahab, A.; Fikri, K.; Tamrin, B.; Hipolito, C.N.; Salleh, S.F. Recent development in ammonia stripping process for industrial wastewater treatment. Int. J. Chem. Eng. 2018, 2018, 1-14. [CrossRef]

33. Maurer, M.; Pronk, W.; Larsen, T.A. Treatment processes for source-separated urine. Water Res. 2006, 40, 3151-3166. [CrossRef] [PubMed]

34. Zarebska, A.; Nieto, D.R.; Christensen, K.V.; Søtoft, L.F. Ammonium fertilizers production from manure: A critical review. Environ. Sci. Technol. 2015, 45, 1469-1521. [CrossRef]

35. Macura, B.; Johannesdottir, S.L.; Piniewski, M.; Haddaway, N.R.; Kvarnström, E. Effectiveness of ecotechnologies for recovery of nitrogen and phosphorus from anaerobic digestate and effectiveness of the recovery products as fertilisers: A systematic review protocol. Environ. Evid. 2019, 8, 1-9. [CrossRef]

36. Vaneeckhaute, C.; Lebuf, V.; Michels, E.; Belia, E.; Vanrolleghem, P.A.; Tack, F.M.G.; Meers, E. Nutrient recovery from digestate: Systematic technology review and product classification. Waste Biomass Valorization 2017, 8, 21-40. [CrossRef]

37. Ozturk, I.; Altinbas, M.; Koyuncu, I.; Arikan, O.; Gomec-Yangin, C. Advanced physico-chemical treatment experiences on young municipal landfill leachates. Waste Manag. 2003, 23, 441-446. [CrossRef]

38. Bonmatí, A.; Flotats, X. Air stripping of ammonia from pig slurry: Characterisation and feasibility as a preor post-treatment to mesophilic anaerobic digestion. Waste Manag. 2003, 23, 261-272. [CrossRef]

39. Lei, X.; Sugiura, N.; Feng, C.; Maekawa, T. Pretreatment of anaerobic digestion effluent with ammonia stripping and biogas purification. J. Hazard. Mater. 2007, 145, 391-397. [CrossRef] [PubMed]

40. Wastewater Engineering, Treatment and Resourse Recovery, 4th ed.; McGraw-Hill Education (Ed.) Metcalf \& Eddy Inc.: New York, NY, USA, 2003.

41. Guštin, S.; Marinšek-Logar, R. Effect of $\mathrm{pH}$, temperature and air flow rate on the continuous ammonia stripping of the anaerobic digestion effluent. Process Saf. Environ. Prot. 2011, 89, 61-66. [CrossRef]

42. El-Gohary, F.A.; Kamel, G. Characterization and biological treatment of pre-treated landfill leachate. Ecol. Eng. 2016, 94, 268-274. [CrossRef]

43. Quan, X.; Wang, F.; Zhao, Q.; Zhao, T.; Xiang, J. Air stripping of ammonia in a water-sparged aerocyclone reactor. J. Hazard. Mater. 2009, 170, 983-988. [CrossRef]

44. Cussler, E.L. Diffusion Mass Transfer in Fluid System, 3rd ed.; Cambridge University Press, Ed.; Cambridge University Press: New York, NY, USA, 2007; ISBN 9780521871211.

45. Hidalgo, D.; Corona, F.; Martín-Marroquín, J.M.; del Álamo, J.; Aguado, A. Resource recovery from anaerobic digestate: Struvite crystallisation versus ammonia stripping. Desalin. Water Treat. 2016, 57, 2626-2632. [CrossRef]

46. Markou, G.; Agriomallou, M.; Georgakakis, D. Forced ammonia stripping from livestock wastewater: The influence of some physico-chemical parameters of the wastewater. Water Sci. Technol. 2017, 75, 686-692. [CrossRef] [PubMed]

47. Saracco, G.; Genon, G. High temperature ammonia stripping and recovery from process liquid wastes. J. Hazard. Mater. 1994, 37, 191-206. [CrossRef]

48. Laureni, M.; Palatsi, J.; Llovera, M.; Bonmatí, A. Influence of pig slurry characteristics on ammonia stripping efficiencies and quality of the recovered ammonium-sulfate solution. J. Chem. Technol. Biotechnol. 2013, 88, 1654-1662. [CrossRef]

49. Desloover, J.; Abate Woldeyohannis, A.; Verstraete, W.; Boon, N.; Rabaey, K. Electrochemical resource recovery from digestate to prevent ammonia toxicity during anaerobic digestion. Environ. Sci. Technol. 2012, 46, 12209-12216. [CrossRef] [PubMed]

50. Luther, A.K.; Desloover, J.; Fennell, D.E.; Rabaey, K. Electrochemically driven extraction and recovery of ammonia from human urine. Water Res. 2015, 87, 367-377. [CrossRef] 
51. Sigurnjak, I.; Brienza, C.; Snauwaert, E.; De Dobbelaere, A.; De Mey, J.; Vaneeckhaute, C.; Michels, E.; Schoumans, O.; Adani, F.; Meers, E. Production and performance of bio-based mineral fertilizers from agricultural waste using ammonia (stripping-)scrubbing technology. Waste Manag. 2019, 89, 265-274. [CrossRef]

52. Speight, J.G. Industrial inorganic chemistry. In Environmental Inorganic Chemistry for Engineers; Elsevier: Amsterdam, The Netherlands, 2017; pp. 111-169.

53. Vaneeckhaute, C.; Meers, E.; Michels, E.; Buysse, J.; Tack, F.M.G. Ecological and economic benefits of the application of bio-based mineral fertilizers in modern agriculture. Biomass Bioenergy 2013, 49, 239-248. [CrossRef]

54. Vaneeckhaute, C. Nutrient Recovery from Bio-Digestion Waste: From Field Experimentation to Model-Based Optimization. Ph.D. Thesis, Ghent University, Ghent, Belgium, 2015.

55. 55. Ammonium Sulfate Prices | Historical \& Current | Intratec.us. Available online: https://www.intratec.us/ chemical-markets/ammonium-sulfate-price (accessed on 30 May 2020).

56. SE Asia Ammonium Sulphate | Fertilizerworks.com. Available online: http://fertilizerworks.com/reports/seasia-am-sulphate (accessed on 31 May 2020).

57. GEA Messo PT Ammonium Sulfate Fertilizer Industry. Available online: https:/www.gea.com/en/binaries/ ammonium-sulfate-crystallization-fertilizer-gea_tcm11-34855.pdf (accessed on 17 June 2020).

58. Kandil, A.-H.T.; Cheira, M.F.; Gado, H.S.; Soliman, M.H.; Akl, H.M. Ammonium sulfate preparation from phosphogypsum waste. J. Radiat. Res. Appl. Sci. 2017, 10, 24-33. [CrossRef]

59. Rauls, M.; Bartosch, K.; Kind, M.; Kuch, S.; Lacmann, R.; Mersmann, A. Influence of impurities on crystallization kinetics-A case study on ammonium sulfate. J. Cryst. Growth 2000, 213, 116-128. [CrossRef]

60. Maurer, M.; Schwegler, P.; Larsen, T.A. Nutrients in urine: Energetic aspects of removal and recovery. Water Sci. Technol. 2003, 48, 37-46. [CrossRef] [PubMed]

61. European Union Council Directive of 12 December 1991 Concerning the Protection of Waters Against Pollution Caused by Nitrates from Agricultural Sources (91/676/EEC). Available online: https:/eur-lex. europa.eu/legal-content/EN/TXT/?uri=CELEX:01991L0676-20081211 (accessed on 2 June 2020).

62. USDA-NRCS National Conservation Practice Standards | NRCS. Available online: https://www.nrcs.usda. gov/wps/portal/nrcs/main/national/technical/cp/ncps/ (accessed on 2 June 2020).

63. USDA-NRCS Agricultural Waste Management Field Handbook | NRCS. Available online: https://www.nrcs. usda.gov/wps/portal/nrcs/detailfull/national/water/? \&cid=stelprdb1045935 (accessed on 2 June 2020).

64. Congreso Nacional de Bolivia. Law No. 1333-Environmental Law. 1992. Available online: https: //digitalrepository.unm.edu/la_energy_policies/271 (accessed on 18 June 2020).

65. Hernández-Padilla, F.; Margni, M.; Noyola, A.; Guereca-Hernandez, L.; Bulle, C. Assessing wastewater treatment in Latin America and the Caribbean: Enhancing life cycle assessment interpretation by regionalization and impact assessment sensibility. J. Clean. Prod. 2017, 142, 2140-2153. [CrossRef]

66. Wang, Q.; Zhang, T.; He, X.; Jiang, R. Assessment of phosphorus recovery from swine wastewater in Beijing, China. Sustainability 2017, 9, 1845. [CrossRef]

67. Ministry of Ecology and Environment. The People's Republic of China Discharge Standard of Water Pollutants for Ammonia Industry (GB 13458-2013). Available online: http://english.mee.gov.cn/Resources/ standards/water_environment/Discharge_standard/201307/t20130705_254903.shtml (accessed on 2 June 2020).

68. Li, W.W.; Sheng, G.P.; Zeng, R.J.; Liu, X.W.; Yu, H.Q. China's wastewater discharge standards in urbanization: Evolution, challenges and implications: Evolution, challenges and implications. Environ. Sci. Pollut. Res. 2012, 19, 1422-1431. [CrossRef] [PubMed]

69. Szymanska, M.; Sosulski, T.; Szara, E.; Was, A.; Sulewski, P.; Van Pruissen, G.W.P.; Cornelissen, R.L. Ammonium sulphate from a bio-refinery system as a fertilizer-agronomic and economic effectiveness on the farm scale. Energies 2019, 12, 4721. [CrossRef]

70. Fuchs, W.; Wang, X.; Gabauer, W.; Ortner, M.; Li, Z. Tackling ammonia inhibition for efficient biogas production from chicken manure: Status and technical trends in Europe and China. Renew. Sustain. Energy Rev. 2018, 97, 186-199. [CrossRef]

71. Branch Environmentl Corp. Ammonia Stripper| Branch Environmental Corp. Available online: https: //www.branchenv.com/ammonia-stripper/ (accessed on 2 June 2020). 
72. Colsen N-Recovery | Colsen. Available online: https://www.colsen.nl/en/services/n-recovery (accessed on 2 June 2020).

73. GNS Digestate Treatment System GNS. Available online: https://www.gns-halle.de/english.html (accessed on 2 June 2020).

74. CMI Europe Environnement Treatment of Odorous and Chemical Air Pollution of Industrial and Collective Plants. Available online: http://www.europe-environnement.com/en/technologies/ (accessed on 2 June 2020).

75. Chen, L.; Cong, R.G.; Shu, B.; Mi, Z.F. A sustainable biogas model in China: The case study of Beijing Deqingyuan biogas project. Renew. Sustain. Energy Rev. 2017, 78, 773-779. [CrossRef]

76. Cao, L.; Wang, J.; Zhou, T.; Li, Z.; Xiang, S.; Xu, F.; Ruan, R.; Liu, Y. Evaluation of ammonia recovery from swine wastewater via a innovative spraying technology. Bioresour. Technol. 2019, 272, 235-240. [CrossRef]

77. Ata, O.N.; Aygun, K.; Okur, H.; Kanca, A. Determination of ammonia removal from aqueous solution and volumetric mass transfer coefficient by microwave-assisted air stripping. Int. J. Environ. Sci. Technol. 2016, 13, 2459-2466. [CrossRef]

78. Ippersiel, D.; Mondor, M.; Lamarche, F.; Tremblay, F.; Dubreuil, J.; Masse, L. Nitrogen potential recovery and concentration of ammonia from swine manure using electrodialysis coupled with air stripping. J. Environ. Manag. 2012, 95, S165-S169. [CrossRef] [PubMed]

79. Tao, W.; Ukwuani, A.T.; Agyeman, F. Recovery of ammonia in anaerobic digestate using vacuum thermal stripping-Acid absorption process: Scale-up considerations. Water Sci. Technol. 2018, 78, 878-885. [CrossRef] [PubMed]

80. Ukwuani, A.T.; Tao, W. Developing a vacuum thermal stripping-Acid absorption process for ammonia recovery from anaerobic digester effluent. Water Res. 2016, 106, 108-115. [CrossRef] [PubMed]

81. Deĝermenci, N.; Ata, O.N.; Yildiz, E. Ammonia removal by air stripping in a semi-batch jet loop reactor. J. Ind. Eng. Chem. 2012, 18, 399-404. [CrossRef]

82. Yuan, M.H.; Chen, Y.H.; Tsai, J.Y.; Chang, C.Y. Removal of ammonia from wastewater by air stripping process in laboratory and pilot scales using a rotating packed bed at ambient temperature. J. Taiwan Inst. Chem. Eng. 2016, 60, 488-495. [CrossRef]

83. Alitalo, A.; Kyrö, A.; Aura, E. Ammonia stripping of biologically treated liquid manure. J. Environ. Qual. 2012, 41, 273-280. [CrossRef]

84. Yang, K.; Oh, C.; Hwang, S. Optimizing volatile fatty acid production in partial acidogenesis of swine wastewater. Water Sci. Technol. 2004, 50, 169-176. [CrossRef]

85. Cheng, H.H.; Narindri, B.; Chu, H.; Whang, L.M. Recent advancement on biological technologies and strategies for resource recovery from swine wastewater. Bioresour. Technol. 2020, 303, 122861. [CrossRef]

86. Heidrich, E.S.; Curtis, T.P.; Dolfing, J. Determination of the internal chemical energy of wastewater. Environ. Sci. Technol. 2011, 45, 827-832. [CrossRef]

87. Bousek, J.; Scroccaro, D.; Sima, J.; Weissenbacher, N.; Fuchs, W. Influence of the gas composition on the efficiency of ammonia stripping of biogas digestate. Bioresour. Technol. 2016, 203, 259-266. [CrossRef] [PubMed]

88. Jiang, M.; Westerholm, M.; Qiao, W.; Wandera, S.M.; Dong, R. High rate anaerobic digestion of swine wastewater in an anaerobic membrane bioreactor. Energy 2020, 193, 116783. [CrossRef]

89. Wang, J.; Westerholm, M.; Qiao, W.; Mahdy, A.; Wandera, S.M.; Yin, D.; Bi, S.; Fan, R.; Dong, R. Enhancing anaerobic digestion of dairy and swine wastewater by adding trace elements: Evaluation in batch and continuous experiments. Water Sci. Technol. 2019, 80, 1662-1672. [CrossRef] [PubMed]

90. Jiang, M.; Qiao, W.; Ren, Z.; Mahdy, A.; Wandera, S.M.; Li, Y.; Dong, R. Influence of operation conditions on methane production from swine wastewater treated by a self-agitation anaerobic reactor. Int. Biodeterior. Biodegrad. 2019, 143, 104710. [CrossRef]

91. Schröder, J.J.; Uenk, D.; Hilhorst, G.J. Long-term nitrogen fertilizer replacement value of cattle manures applied to cut grassland. Plant Soil 2007, 299, 83-99. [CrossRef]

92. Le Corre, K.; Valsami-Jones, E.; Hobbs, P.; S, P. Phosphorous recovery from waste water by struvite crysatllisation: A review. Crit. Rev. Environ. Sci. Technol. 2009, 39, 433-477. [CrossRef]

93. Iglesia, A. La Estimating the thermodynamic properties of phosphate minerals at high and low temperature from the sum of constituent units. Estud. Geol. 2009, 65, 109-119. [CrossRef] 
94. Rahman, M.M.; Salleh, M.A.M.; Rashid, U.; Ahsan, A.; Hossain, M.M.; Ra, C.S. Production of slow release crystal fertilizer from wastewaters through struvite crystallization-A review. Arab. J. Chem. 2014, 7, 139-155. [CrossRef]

95. Ye, Z.; Chen, S.; Lu, M.; Shi, J.; Lin, L.; Wang, S. Recovering phosphorus as struvite from the digested swine wastewater with bittern as a magnesium source. Water Sci. Technol. 2011, 64, 334-341. [CrossRef]

96. La, J.; Kim, T.; Jang, J.K.; Chang, I.S. Ammonia nitrogenrRemoval and recovery from swine wastewater by microwave radiation. Environ. Eng. Res. 2014, 19, 381-385. [CrossRef]

97. Viancelli, A.; Kunz, A.; Steinmetz, R.L.R.; Kich, J.D.; Souza, C.K.; Canal, C.W.; Coldebella, A.; Esteves, P.A.; Barardi, C.R.M. Performance of two swine manure treatment systems on chemical composition and on the reduction of pathogens. Chemosphere 2013, 90, 1539-1544. [CrossRef] [PubMed]

98. Wu, D.; Zheng, S.; Ding, A.; Sun, G.; Yang, M. Performance of a zero valent iron-based anaerobic system in swine wastewater treatment. J. Hazard. Mater. 2015, 286, 1-6. [CrossRef] [PubMed]

99. Cheng, D.L.; Ngo, H.H.; Guo, W.S.; Liu, Y.W.; Zhou, J.L.; Chang, S.W.; Nguyen, D.D.; Bui, X.T.; Zhang, X.B. Bioprocessing for elimination antibiotics and hormones from swine wastewater. Sci. Total Environ. 2017, 621, 1664-1682. [CrossRef]

100. Girault, R.; Rousseau, P.; Steyer, J.P.; Bernet, N.; Béline, F. Combination of batch experiments with continuous reactor data for ADM1 calibration: Application to anaerobic digestion of pig slurry. Water Sci. Technol. 2011, 63, 2575-2582. [CrossRef] [PubMed]

101. Kim, W.; Shin, S.G.; Cho, K.; Lee, C.; Hwang, S. Performance of methanogenic reactors in temperature phased two-stage anaerobic digestion of swine wastewater. J. Biosci. Bioeng. 2012, 114, 635-639. [CrossRef] [PubMed]

102. Kim, W.; Cho, K.; Lee, S.; Hwang, S. Comparison of methanogenic community structure and anaerobic process performance treating swine wastewater between pilot and optimized lab scale bioreactors. Bioresour. Technol. 2013, 145, 48-56. [CrossRef]

103. Zhai, W.; Qin, T.; Guo, T.; Khan, M.I.; Tang, X.; Xu, J. Arsenic transformation in swine wastewater with low-arsenic content during anaerobic digestion. Water (Switzerland) 2017, 9, 826. [CrossRef]

104. Auphimai, C.; Rukruam, W.; Chaiprasert, P. Efficacies of various inoculum sources on methane production from agro-industrial wastewaters. Energy Procedia 2014, 52, 167-172. [CrossRef]

105. Ho, L.; Ho, G. Mitigating ammonia inhibition of thermophilic anaerobic treatment of digested piggery wastewater: Use of pH reduction, zeolite, biomass and humic acid. Water Res. 2012, 46, 4339-4350. [CrossRef]

106. Córdoba, V.; Fernández, M.; Santalla, E. The effect of different inoculums on anaerobic digestion of swine wastewater. J. Environ. Chem. Eng. 2016, 4, 115-122. [CrossRef]

107. Córdoba, V.; Fernández, M.; Santalla, E. The effect of substrate/inoculum ratio on the kinetics of methane production in swine wastewater anaerobic digestion. Environ. Sci. Pollut. Res. 2018, 25, 21308-21317. [CrossRef] [PubMed]

108. Cattaneo, M.; Finzi, A.; Guido, V.; Riva, E.; Provolo, G. Effect of ammonia stripping and use of additives on separation of solids, phosphorus, copper and zinc from liquid fractions of animal slurries. Sci. Total Environ. 2019, 672, 30-39. [CrossRef]

109. Belmonte, M.; Hsieh, C.-F.; Figueroa, C.; Campos, J.L.; Vidal, G. Effect of free ammonia nitrogen on the methanogenic activity of swine wastewater. Electron. J. Biotechnol. 2011, 14. [CrossRef]

110. Huang, W.; Zhao, Z.; Yuan, T.; Lei, Z.; Cai, W.; Li, H.; Zhang, Z. Effective ammonia recovery from swine excreta through dry anaerobic digestion followed by ammonia stripping at high total solids content. Biomass Bioenergy 2016, 90, 139-147. [CrossRef]

111. Huang, H.; Guo, G.; Zhang, P.; Zhang, D.; Liu, J.; Tang, S. Feasibility of physicochemical recovery of nutrients from swine wastewater: Evaluation of three kinds of magnesium sources. J. Taiwan Inst. Chem. Eng. 2017, 70, 209-218. [CrossRef]

112. Huang, H.; Xiao, D.; Liu, J.; Hou, L.; Ding, L. Recovery and removal of nutrients from swine wastewater by using a novel integrated reactor for struvite decomposition and recycling. Sci. Rep. 2015, 5, 1-13. [CrossRef]

113. Deng, L.; Yang, H.; Liu, G.; Zheng, D.; Chen, Z.; Liu, Y.; Pu, X.; Song, L.; Wang, Z.; Lei, Y. Kinetics of temperature effects and its significance to the heating strategy for anaerobic digestion of swine wastewater. Appl. Energy 2014, 134, 349-355. [CrossRef] 
114. Van der Heyden, C.; Demeyer, P.; Volcke, E.I.P. Mitigating emissions from pig and poultry housingfacilities through air scrubbers and biofilters: State-of-the-art andperspectives. Biosyst. Eng. 2015, 134, 74-93. [CrossRef]

115. Liao, P.H.; Chen, A.; Lo, K.V. Removal of nitrogen from swine manure wastewaters by ammonia stripping. Bioresour. Technol. 1995, 54, 17-20. [CrossRef]

116. Zhang, R.; Anderson, E.; Addy, M.; Deng, X.; Kabir, F.; Lu, Q.; Ma, Y.; Cheng, Y.; Liu, Y.; Chen, P.; et al. An innovative intermittent-vacuum assisted thermophilic anaerobic digestion process for effective animal manure utilization and treatment. Bioresour. Technol. 2017, 244, 1073-1080. [CrossRef]

117. Wang, Y.; Guo, W.; Yen, H.W.; Ho, S.H.; Lo, Y.C.; Cheng, C.L.; Ren, N.; Chang, J.S. Cultivation of Chlorella vulgaris JSC-6 with swine wastewater for simultaneous nutrient/COD removal and carbohydrate production. Bioresour. Technol. 2015, 198, 619-625. [CrossRef] [PubMed]

118. Wang, Y.; Ho, S.H.; Cheng, C.L.; Nagarajan, D.; Guo, W.Q.; Lin, C.; Li, S.; Ren, N.; Chang, J.S. Nutrients and COD removal of swine wastewater with an isolated microalgal strain Neochloris aquatica CL-M1 accumulating high carbohydrate content used for biobutanol production. Bioresour. Technol. 2017, 242, 7-14. [CrossRef] [PubMed]

119. Qu, W.; Zhang, C.; Zhang, Y.; Ho, S.H. Optimizing real swine wastewater treatment with maximum carbohydrate production by a newly isolated indigenous microalga Parachlorella kessleri QWY28. Bioresour. Technol. 2019, 289, 121702. [CrossRef] [PubMed]

120. Luo, L.; He, H.; Yang, C.; Wen, S.; Zeng, G.; Wu, M.; Zhou, Z.; Lou, W. Nutrient removal and lipid production by Coelastrella sp. in anaerobically and aerobically treated swine wastewater. Bioresour. Technol. 2016, 216, 135-141. [CrossRef]

121. Guo, G.; Cao, W.; Sun, S.; Zhao, Y.; Hu, C. Nutrient removal and biogas upgrading by integrating fungal-microalgal cultivation with anaerobically digested swine wastewater treatment. J. Appl. Phycol. 2017, 29, 2857-2866. [CrossRef]

122. Sui, Q.; Zhu, Z.; Dong, H.; Wang, Y. Nitrogen removal from anaerobically digested swine wastewater through combined ammonia stripping and membrane bioreactor processes. Trans. ASABE 2015, 58, 1289-1298.

123. Zhang, M.; Lawlor, P.G.; Hu, Z.; Zhan, X. Nutrient removal from separated pig manure digestate liquid using hybrid biofilters. Environ. Technol. (United Kingdom) 2013, 34, 645-651. [CrossRef]

124. Song, Y.; Qiu, G.; Yuan, P.; Cui, X.; Peng, J.; Zeng, P. Nutrients removal and recovery from anaerobically digested swine wastewater by struvite crystallization without chemical additions. J. Hazard. Mater. 2011, 190, 140-149. [CrossRef]

125. Lin, H.; Lin, Y.; Wang, D.; Pang, Y.; Zhang, F.; Tan, S. Ammonium removal from digested effluent of swine wastewater by using solid residue from magnesium-hydroxide flue gas desulfurization process. J. Ind. Eng. Chem. 2018, 58, 148-154. [CrossRef]

126. Ashrafizadeh, S.N.; Khorasani, Z. Ammonia removal from aqueous solutions using hollow-fiber membrane contactors. Chem. Eng. J. 2010, 162, 242-249. [CrossRef]

127. Cao, L.; Wang, J.; Xiang, S.; Huang, Z.; Ruan, R.; Liu, Y. Nutrient removal from digested swine wastewater by combining ammonia stripping with struvite precipitation. Environ. Sci. Pollut. Res. 2019, 26, 6725-6734. [CrossRef] [PubMed]

128. Quan, X.; Ye, C.; Xiong, Y.; Xiang, J.; Wang, F. Simultaneous removal of ammonia, P and COD from anaerobically digested piggery wastewater using an integrated process of chemical precipitation and air stripping. J. Hazard. Mater. 2010, 178, 326-332. [CrossRef] [PubMed]

129. Zou, M.; Dong, H.; Zhu, Z.; Zhan, Y. Optimization of ammonia stripping of piggery biogas slurry by response surface methodology. Int. J. Environ. Res. Public Health 2019, 16, 3819. [CrossRef] [PubMed]

(C) 2020 by the authors. Licensee MDPI, Basel, Switzerland. This article is an open access article distributed under the terms and conditions of the Creative Commons Attribution (CC BY) license (http://creativecommons.org/licenses/by/4.0/). 